\title{
A Multi-Factorial Review of Repowering Wind Generation Strategies
}

\author{
Isabel C. Gil-García ${ }^{1}$ (D) Ana Fernández-Guillamón ${ }^{2}\left(\mathbb{D}\right.$, M. Socorro García-Cascales $^{3}$ (D) \\ and Angel Molina-García 2,*(D) \\ 1 Faculty of Engineering, Distance University of Madrid (UDIMA), c/Coruña, km 38500, 28400 Madrid, Spain; \\ isabelcristina.gil@udima.es \\ 2 Department of Automatics, Electrical Engineering and Electronic Technology, Universidad Politécnica de \\ Cartagena, 30202 Cartagena, Spain; ana.fernandez@upct.es \\ 3 Department of Electronics, Technology of Computers and Projects, Universidad Politécnica de Cartagena, \\ 30202 Cartagena, Spain; socorro.garcia@upct.es \\ * Correspondence: angel.molina@upct.es
}

Citation: Gil-García, I.C.;

Fernández-Guillamón, A.;

García-Cascales, M.S.; Molina-García,

A. A Multi-Factorial Review of

Repowering Wind Generation

Strategies. Energies 2021, 14, 6280.

https://doi.org/10.3390/en14196280

Academic Editor: Davide Astolfi

Received: 14 June 2021

Accepted: 22 September 2021

Published: 2 October 2021

Publisher's Note: MDPI stays neutral with regard to jurisdictional claims in published maps and institutional affiliations.

Copyright: (c) 2021 by the authors. Licensee MDPI, Basel, Switzerland. This article is an open access article distributed under the terms and conditions of the Creative Commons Attribution (CC BY) license (https:// creativecommons.org/licenses/by/ $4.0 /)$.

\begin{abstract}
The integration of renewables into power systems is a key transformation for mitigating climate change and reducing fossil-fuel dependence. Among the different resources, wind participation has become crucial in recent decades-both onshore and offshore wind power plants. However, assuming the useful life of the wind turbines at approximately 20 years, different solutions should be discussed to overcome the turbine's aging problem. In the coming years, some countries within the wind sector will face the decision of partially or totally repowering or dismantling their turbines. This paper reviews different repowering strategies and contributions from a multifactorial perspective. A set of categories is defined by the authors and those multifactorial parameters are then classified according to such categories: technical, economic, environmental, social, and political. From each category, the most relevant factors to be considered for repowering decision-making purposes are identified and discussed. According to the specific literature, more than $90 \%$ of the reviewed contributions are focused on onshore wind power plant repowering actions. This percentage is in line with onshore and offshore wind generation units installed in recent decades. The reviewed studies show that Germany has a major number of contributions. Regarding offshore repowering strategies, all contributions propose a multifactorial analysis, in contrast to onshore repowering strategies where only $68 \%$ of the authors carry out a multifactorial analysis. The revised repowering methodologies and the categorization of factors can also be used by the repowering market, as a useful tool in the near future.
\end{abstract}

Keywords: lifetime; multifactorial analysis; repowering; wind energy

\section{Introduction}

In recent decades, power systems have been constructed to replace pollutant generation units (mainly fossil fuels) with Renewable Energy Sources (RESs) [1]. This electrical transition is relevant worldwide; more than $25 \%$ of total electricity generation was derived from RESs in 2018, compared to 18\% in 1990. Indeed, the current energy transition is mostly focused on the depletion of fossil fuels and the need to reduce greenhouse gas emissions [2]. This alternative energy scenario implies different sectors beyond power markets, such as heating and cooling energy demand, industrial energy requirements and transportation [3]. An example is the European Union (EU) target of attaining 15\% and 30\% reduction in the average emissions of the continent's fleet of new cars by 2025 and 2030, respectively, which should be further prioritized [4]. In a similar way, Wang et al. [5] provide a comprehensive overview based on the pattern of mitigation targets set by global firms. Nevertheless, these efforts must be reinforced to achieve the ambitious energy road-maps and environmental targets proposed by different agents, with initiatives mainly focused on RES integration 
into power systems [6-8]. Governments and policymakers in the EU region, for example, must put in place suitable economic and energy policies to promote a general development and integration of RESs towards achieving environmental sustainability of this region [9]. Moreover, Ediger [10] affirms that we are currently in a transition to a more sustainable energy regime, where gas can be considered as a bridge fuel. More recently, the COVID-19 pandemic has caused the sharpest decline in nearly 30 years globally, having a devastating effect on the global renewable energy supply chain [11]. Barbier et al. [12] conclude that the pandemic is likely to further undermine progress towards sustainable development goals by 2030, which were already faltering even before the outbreak, as previously stated. In the same way, Madurai-Elavarasan et al. [13] indicate that the progress towards sustainability is insufficient, and we need a more resilient society working in parallel with the environment.

With regard to RES integration into power systems, both governments and citizens are now promoting their development and participation in power systems [14]. Fleta-Asín et al. [15] affirm that public-private partnerships emerge as an important mechanism widely used to deliver public infrastructure services, and the electricity sector is not an exception. The deployment of well-established technologies-mainly hydro, as well as other mature technologies, such as wind and solar photovoltaic-has risen quickly, substantially increasing the confidence in these technologies, reducing costs and creating new opportunities [16]. Other authors also propose additional RESs implemented as power generation units, such as thermal solar energy, geothermal energy, ocean energy (tide and wave), and bioenergy [14]. Among these renewable resources, wind energy can be identified as the most economic, prominent, and qualified resource for electricity generation. Indeed, wind is currently playing a relevant role in power systems [17,18], although fossil fuels and conventional energy technologies still dominate the European electricity market at around $75 \%$ generation [19]. More than 200 scientific contributions published between 2009 and 2019 are reviewed in [20] to report on the public engagement with such wind energy resources. Figure 1 depicts the electricity generation evolution in the world in recent decades [21].
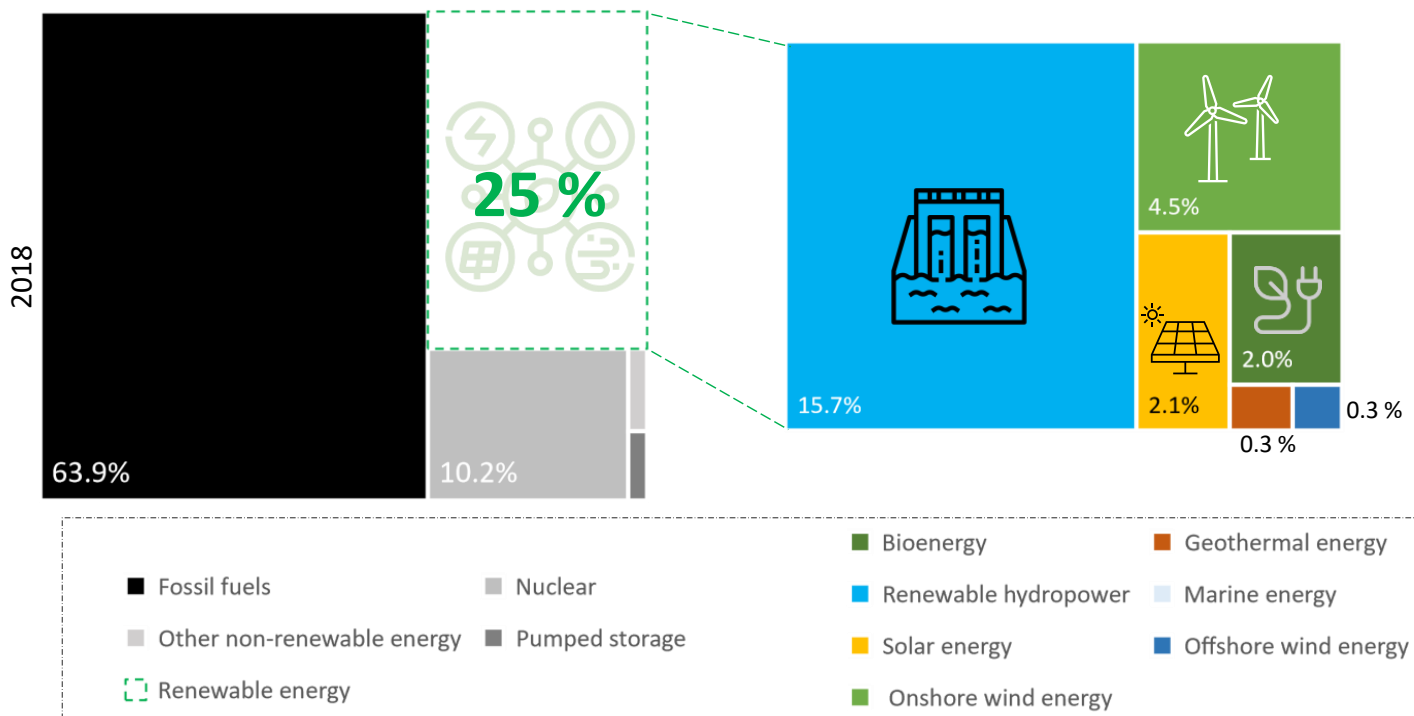

- Geothermal energy

Marine energy

- Offshore wind energy

Figure 1. Electricity generation evolution in the world (source: own elaboration). 
Global installed wind capacity has been increasing non-stop since 2001, and accounted for more than $700 \mathrm{GW}$ in 2020 [21]. Consequently, the lifespans of most current wind power plants have already reached their end-or will reach in the near future-assuming an approximate useful life of 20 years [22]. As an example, more than $30 \%$ of the installed wind energy capacity in Germany will leave the renewable energy funding regime between 2020 and 2025 [23], and by the end of the 2020s, the first large demands on the wind turbine end-of-life will become evident in the USA, with $32 \%$ of current USA Global Wind Inventory for Future Decommissioning [24]. In parallel with this RES development, Hache et al. [25] indicate the relevant amount of scientific contributions, along with the numerous reports issued by different government agencies, published during the last two decades and focused on RES integration into power systems. Serrano- González et al. [26] affirm that research works analyzing the renewable generation lifespan issue have been only published within the last ten years. In addition, long-term horizon planning frequently addresses the generation expansion planning problem [27], not only through the economic issue but also the environmental scenario. Different strategies can be found in recent contributions regarding the renewable generation lifespan issue-life extension, repowering or decommissioning. Comprehensive analysis of current and potential decommissioning scenarios for end-of-life composite wind blades can be found in [28,29]. Life extension strategies for offshore wind power plants based on techno-economic characteristics are reviewed by Pakenham et al. [30]. A necessary dialogue among stakeholders aiming to regulate and adequately prepare the upcoming offshore wind power plant decommissioning in Europe is presented in [31]. Moreover, Piel et al. [32] also indicate that the dismantling, disposal and recycling of numerous aging turbines will become a major challenge for the wind energy sector in the coming decade. However, there is a lack of contributions focused on reviewing these proposals from a multifactorial point of view. To overcome this drawback, the present paper discusses and reviews the repowering wind power plant strategies proposed in the selected literature. A set of categories are thus defined by the authors and the multifactorial parameters are then classified according to such categories: technical, economic, environmental, social, and political. In this way, Sawant et al. [33] recently concluded that repowering wind power plants and the different solutions found in the specific literature would surely give rise to new review works in the future. The authors emphasize that the main objective of this paper is to carry out a literature review of contributions published during the last decades in the specific literature through simple statistical indicators, but not to define or propose a statistical model.

The rest of the paper is structured as follows: Section 2 describes the methods proposed; Sections 3 and 4 study the contributions of onshore and offshore repowering, respectively; Section 5 discusses the results; and finally, conclusions are given in Section 6 .

\section{Methods}

The methods used in this review work are based on the Preferred Reporting Items for Systematic Reviews and Meta-Analyses (PRISMA) [34]. The main objective is to guarantee the quality of the searching process and selection of contributions by researchers. In our work, the proposed general has two main steps: systematic review and meta-analysis. Figure 2 summarizes the proposed methods. From the objectives described in Section 1 , this literature review aims to provide a detailed analysis of the works related to the onshore and offshore wind power plants' repowering solutions. The time period under analysis is 2000-2021, in line with other works cited in Section 1. Four stages can be identified in this systematic review: (i) identification, (ii) screening, (iii) eligibility, and (iv) included; see Figure 2. By considering the keywords that define the general objective of this work, and using current available scientific databases (ScienceDirect, Google Scholar, Web of Science, and Scopus), 1880 articles were initially selected for potential review. Analyzing the title and abstract, we identified 457 duplicated works and 1238 contributions not directly related to the review objectives. Subsequently, 185 contributions were selected to be reviewed. The full text of each work was then reviewed in the eligibility stage, discarding such works 
where the wind resource was not the main renewable source, as well as those contributions not directly focused on the repowering problem. After this process, 108 works were rejected, and three additional works from the reference lists were included in the total number of works to be considered for this analysis. Finally, 80 contributions were selected for our study.

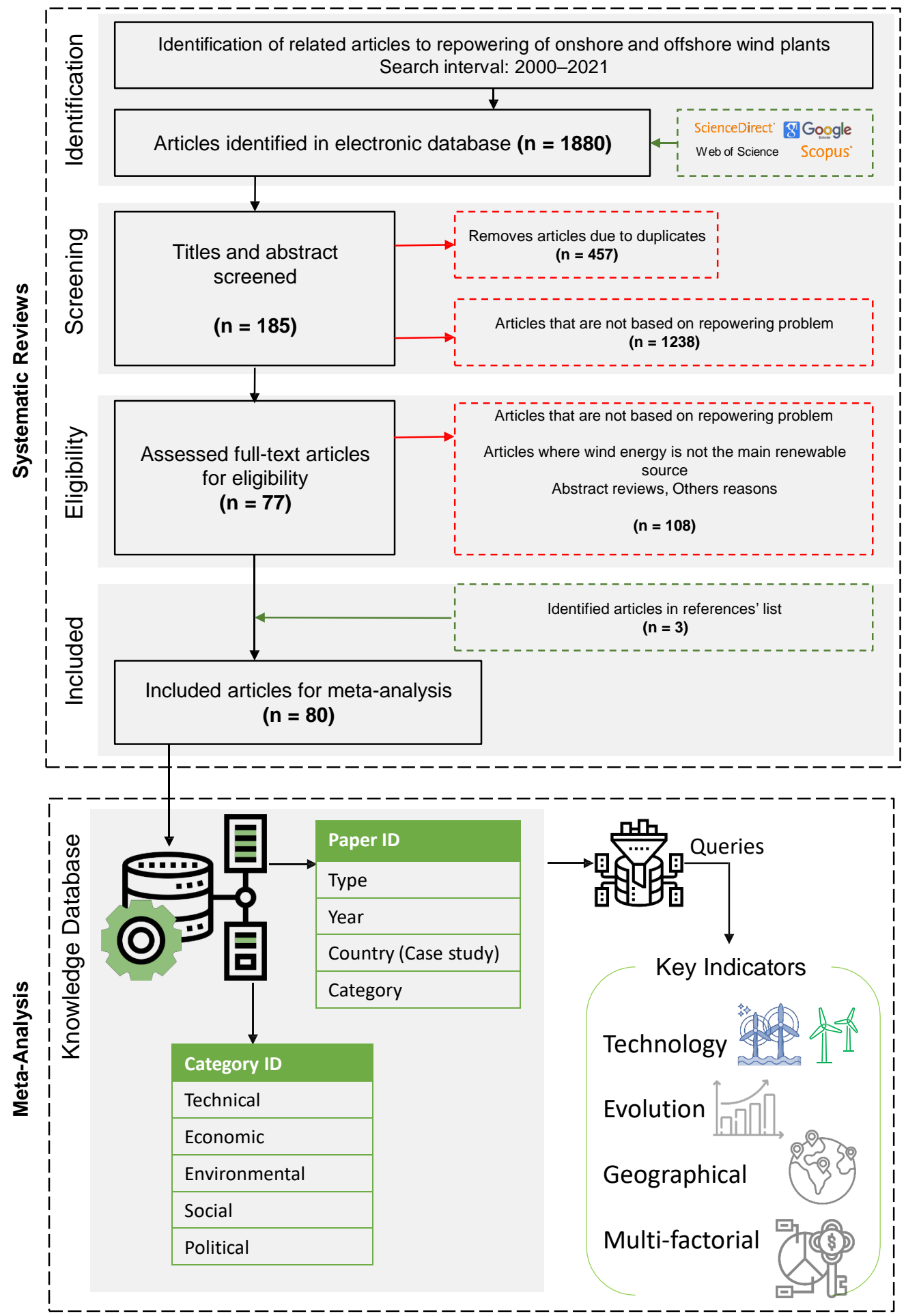

Figure 2. Methods proposed: Systematic Review and Meta-Analysis.

In the meta-analysis process, two stages can be identified: the design of the knowledge database and the implementation and coding of queries to extract key indicators. Taking 
into account the objectives of the research and analysis of the contributions, a knowledge database is proposed by the authors from a conceptual model of entities and relationships, able to be transformed into a standardized logical design and avoiding duplicated information. In the implementation of the database, each dataset extracted from the different works was inserted and processed through different query techniques: filters, totals, subtotals, groupings, and so forth. The key indicators are detailed as follows:

- Evolution of publications: a first analysis of the annual evolution of publications was carried out to identify the period in which these studies are the most relevant and interesting;

- Classification by technology: given the technological maturity of both onshore and offshore wind, each of them was accounted for separately;

- Geographical classification: a study of the case studies was carried out by country to identify the geographical areas with the greatest impact in the publications and their possible association with other indicators of the sector;

- Multi-Category analysis: all the factors that involve the repowering process of the wind power plants of the selected studies were analyzed. Supported by the categories of factors involved in the optimal selection of wind sites [34], five general categories are proposed: technical, economic, environmental, social, and political. Subsequently, the most relevant factors for each category were identified. Table 1 shows the main factors included in each category. In some cases, it can be difficult to determine if a factor refers to one category or another (i.e., 'noise' and 'visual impact' could be considered as 'Environmental' or 'Social'). To overcome such adversity, the authors found out another review where it is stated that social acceptance is focused on the aerodynamic noise and the distance from the turbine [35]. Hence, both 'noise' and 'visual impact' are considered within the 'Social' category.

Table 1. Main factors by categories.

\begin{tabular}{ll}
\hline Category & Factors \\
\hline Technical & Selection and location of wind turbines. \\
& New capacity to install. \\
& Annual electricity generation. \\
& Capacity factor \\
& Losses due to the wake effect \\
& Changes in infrastructures (electrical work, foundations) \\
Economic & Costs of the infrastructure associated with the investment (CAPEX). \\
& Cost focused on the exploitation phase (OPEX). \\
& Financial indicators (Net present value, Internal rate of return). \\
& Levelized cost of energy. \\
Environmental & Reduction emissions CO 2. \\
& Flora and fauna impact. \\
Social & Visual impact. \\
& The noise impact in quality of life. \\
& Land use. \\
& Distance to urban areas, roads or other economic activities \\
& Employability \\
& Political measures established in favor of renewable energies. \\
& Incentives and taxes.
\end{tabular}

\section{Repowering Strategies for Onshore Wind Power Plants}

In this section, the different works related to the onshore wind power plant repowering are described and reviewed. An additional classification (multifactorial analysis) is included according to the factors categorized in Table 1. In fact, there are several studies that simultaneously analyze and consider some of these categories. 


\subsection{Multi-Category Analysis}

Some authors consider different categories when analyzing repowering options for onshore wind power plants. Table 2 summarizes these contributions and identified the categories to be considered by each work.

Table 2. Contributions with several categories in onshore wind repowering methodologies. Period (2000-2021).

\begin{tabular}{|c|c|c|c|c|c|c|c|}
\hline Ref. & Year & Technical & Economic & $\begin{array}{l}\text { Categories } \\
\text { Environmental }\end{array}$ & Political & Social & Region \\
\hline [36] & 2001 & $x$ & & $x$ & & & Netherlands \\
\hline [37] & 2006 & & & $x$ & & $x$ & Denmark \\
\hline [38] & 2010 & & & $x$ & & $x$ & Germany \\
\hline [39] & 2010 & & & $x$ & $x$ & & Germany \\
\hline [40] & 2010 & & $x$ & & $x$ & $x$ & Denmark \\
\hline [41] & 2011 & $x$ & $x$ & $x$ & & & Spain \\
\hline [42] & 2011 & $x$ & $x$ & & $x$ & & Worldwide \\
\hline [43] & 2011 & $x$ & $x$ & & & & Denmark \\
\hline [44] & 2011 & $x$ & $x$ & & $x$ & $x$ & Germany \\
\hline [45] & 2011 & $\mathrm{X}$ & & $x$ & & & Germany \\
\hline [46] & 2013 & $x$ & $x$ & & $x$ & & Germany \\
\hline [47] & 2013 & $x$ & $x$ & & & & Greece \\
\hline [48] & 2013 & $x$ & $x$ & & $x$ & & USA \\
\hline [49] & 2013 & $x$ & $x$ & & $x$ & & Spain \\
\hline [50] & 2015 & & $x$ & $x$ & $x$ & $x$ & Czech Republic \\
\hline [51] & 2015 & $x$ & $x$ & & $x$ & & Spain \\
\hline [52] & 2015 & $x$ & $x$ & & $x$ & & India \\
\hline [53] & 2015 & $x$ & & $x$ & & & Norway \\
\hline [54] & 2015 & $x$ & $x$ & & & & Germany \\
\hline [55] & 2016 & $x$ & $x$ & & & & USA \\
\hline [56] & 2016 & $x$ & $x$ & $x$ & $x$ & & Spain \\
\hline [57] & 2016 & $x$ & $x$ & & & & India \\
\hline [58] & 2017 & & $x$ & & $x$ & & Germany \\
\hline [59] & 2017 & $x$ & $x$ & & & & Italy \\
\hline [60] & 2018 & $x$ & $x$ & & & & Germany \\
\hline [61] & 2018 & $x$ & & & $x$ & & Spain \\
\hline [62] & 2018 & $x$ & $x$ & & & & Spain \\
\hline [63] & 2018 & $x$ & $x$ & & $x$ & $x$ & DE, ES, DK, UK \\
\hline [64] & 2019 & $x$ & $\mathrm{X}$ & & $x$ & & Germany \\
\hline [65] & 2019 & $x$ & & $x$ & & & Spain \\
\hline [66] & 2019 & $x$ & $x$ & & & & France \\
\hline [67] & 2019 & $x$ & $x$ & & & & Mexico \\
\hline [68] & 2020 & $x$ & & & $x$ & $X$ & Denmark \\
\hline [69] & 2020 & $x$ & & $x$ & & & USA \\
\hline [70] & 2021 & $x$ & $x$ & & & & Brazil \\
\hline [71] & 2021 & $x$ & $x$ & & $x$ & & Germany \\
\hline [72] & 2021 & $x$ & $x$ & & & & Denmark \\
\hline
\end{tabular}

In 2001, Klunne et al. studied the partial repowering of individual wind turbines, or total repowering of wind plants in their entirety, considering the technical and political aspects in the Netherlands [36]. To achieve the expected long-term installed capacity objectives by combining both repowering strategies, they foresee an increase of $512 \mathrm{MW}$ of installed wind power capacity. In 2013, the National Renewable Energy Laboratory (NREL) developed a technical report also based on partial and total repowering in USA scenarios [48]. This report used the NREL's System Advisor Model (SAM) to predict the 
estimated cash flows for different electricity generation technologies. The partial repowering was less economically attractive considering the electricity generation. Similarly, Paul and Prabu [57] carried out a total repowering assessment of a wind power plant made up of old 2-bladed wind turbines in Gudimangalam (India), considering technical and economic aspects. The total repowering was accomplished through several stages of partial repowering (i.e., replacement of only few of the turbines). In fact, the presented methodology optimized the partial repowering options, thus resulting in the best possible total repowering. The technical analysis was carried out using the WAsP software, and the economic feasibility was studied based on several economic indices, such as Annual Levelized Cost of Generation (ALCoG), PBP or IRR. In 2006, Moller analyzed the visual impact on landscapes and the population during a repowering period in Northern Jutland (Denmark) [37]. A Geographical Information System (GIS) analysis was used to find relations among population, landscapes, and the wind turbine development from 1982 to 2007. The repowering of wind power plants was justified due to the increase in technological efficiency, but implied an irregular development regarding visual space and social/public ownership, which may reduce the wind installation acceptance. A similar study was conducted by Ohl and Eichhorn in 2010 in West Saxony (Germany), also using a GIS-based model [39]. In this case, they evaluated the bio-physical and administrative siting requirements for wind turbines of specific sizes, with the characteristics of the land, finding severe difficulties due to the differences between the spatial planning policy for wind energy at the state level and the economic planning for wind energy at the federal level. GIS was also used in a work published in 2017, where Serri et al. [59] studied repowering in Italy, taking into account technical and economic factors. They proposed three hypotheses: the real case (the capacity of each repowered plant is the same as the end-of-life plant) and two more fictitious scenarios: the capacity of each repowered plant was 1.5 and 2 times that of the end-of-life plant. An incentive fee of 10-25€/MWh was estimated to be necessary to ensure that results were economically viable.

Meyerhoff et al. focused on environmental and social factors in two different regions of Germany (Westsachsen and Nordhessen) through choice experiments conducted in May and June 2008 [38]. In total, they interviewed more than 700 people, providing three different choices of wind power plant (including the size of the wind turbines, minimum distance to residential areas, impact on red kite population and the monthly surcharge to the power bill). According to the interview results, people in Westsachsen and Nordhessen preferred wind turbines to be further away from residential areas and consider the wind turbines' impact on biodiversity as negative. A similar study was conducted in 2015 by Frantal at the government level and members of society in the Czech Republic, including economic, social, environmental, and political factors [50]. In total, $95 \%$ of the government respondents, from an economic point of view, accepted the repowering, while the community, $59 \%$. With regard to social factors, $95 \%$ of the government respondents rejected repowering due to the majority opposition of neighbors. The community rejected it $(63 \%)$ due to the visual impact. In general, the positive impact on repowering is palpable in the results, compared to the negative ones.

In 2010, Sperling et al. proposed a wind energy support system that can coordinate several policy domains (i.e., financial, planning and administrative, and local and regional development perspectives), both to build new wind power plants and to repower old wind turbines [40]. In this way, through the wide perspective obtained, it is possible to help develop and evaluate wind energy and planning policy by analyzing their effects on these fields. In 2011, Del Rio et al. [42] analyzed the benefits, drivers, and barriers of repowering as well as the different experiences of leading countries in onshore wind power (Denmark, Germany, Spain, and California, USA). They extracted the main factors involved and carried out a multi-criteria analysis with political, technical, and economic factors. It showed that the capacity factor and investment costs were relevant variables within the repowering decision-making process. A similar study was also developed in 2011 by Himpler and Madlener, but focused on Denmark [43]. The probability of 
annual repowering was determined from the income and investment costs, concluding that the uncertainty of the income costs is a relevant barrier in repowering, and a greater contribution of government incentives was vital. In 2015, Weiss et al. proposed several repowering scenarios for Germany [54]. The first scenario was designed according to the height of the turbine limited by legislation $(100 \mathrm{~m})$; the rest of the scenarios were based on more modern technologies, without considering the height limitation. They found that the scenarios where height was not limited gave positive technical and economic results. Moreover, they concluded that laws had to be updated in parallel with technology or be mitigated with instruments of subsidies in order to favor repowering. Recently, Madlener et al. analyzed the evolution of the regulatory framework of RES laws in Germany, and proposed a model to determine the optimal moment to repower according to the EEG ('Erneuerbare Energien Gesetz', Renewable Energy Law 2017), which also considers technical and economic factors [64]. Economically, early repowering is more beneficial, and it is highly influenced by the rate granted at the beginning of the project. A case study developed in Spain by Castro et al. in 2011 highlighted the environmental and economic advantages of repowering [41]. By using the existing civil infrastructures, a decrease in visual and acoustic impacts was obtained, whereas it increased the production and return on investment in less than 5 years. A similar study was also conducted by Madlener et al., but focused on Germany [44]. The economic evaluation of repowering projects could be positive thanks to different aspects such as incentives, the simplification in the start-up process, the technical improvements, and the social acceptance caused mainly by changes in the tax legislation. Zimmermann et al. developed a methodology to optimize the repowering process, based on technical and environmental factors $\left(\mathrm{CO}_{2}\right.$ emissions), as well as energy demand. Such methodology was applied to different scenarios for Germany during the period 2002-2010 [45].

Technical, economic, and political factors were studied in several papers published in 2013. Jansen identified which variables have the greatest influence on repowering in Germany [46]. He indicated that the main variable in the repowering decision was the type of wind turbine chosen and, to a lesser extent, the incentive policies decreed until then in the country. Therefore, the viability of the project depended on the capacity-production relationship. Konstantinos analyzed the factors that influenced the early and necessary repowering of a wind power plant in Greece, caused by poor production results far from the initial forecasts of the project [47]. New descriptive statistical studies of the wind resource in the area and the replacement of wind turbines with new technologies, using updated tools such as WAsP, guaranteed the viability of the project. Focusing on Spain, in [49], it was concluded that public policies would significantly affect financial analysis. In fact, the repowering project would not be feasible in the absence of feed-in tariffs (FITs). Therefore, they are effective in promoting repowering. The most relevant variables in the decision to repower a wind power plant are greater productive efficiency, capital investments, and the increase in the installed capacity. On the other hand, operation and maintenance costs have a smaller influence on the repowering decision. A sensitivity analysis completed the investigation, identifying that, with a $1 \%$ increase in production, the effect on the Net Present Repowering Value (NPRV) was greater than the 1\% decrease in investment costs per kWh.

The relationship between economic incentives decreed by different governments and the economic viability of the repowering of wind power plants was analyzed in 2015 in countries with high potential for repowering. In the case of Spain, Colmenar-Santos et al. showed that in many cases it is more feasible to repower than to construct new power plants [51]. The costs of dismantling the eliminated turbines were absorbed by the production profits of the new wind turbines in more beneficial conditions with respect to wind potential. In fact, they emphasized that repowering required a specific framework, both technical and remunerative. In the case of India, Prabu et al. [52] pointed out that government policies must evolve in order to benefit investors. They studied the economic advantages of partial repowering compared to total repowering, provided that the design 
of the new turbines is optimal according to the potential wind. In 2017, Romano et al. tried to resolve the dilemma about which the political instrument was the most appropriate in repowering from the point of view of uncertainty: quotas and FITs or British Renewable Obligation Certificates (ROCs), both mandatory [58]. The methodology was based on a dynamic programming model, concluding that the price certainty according to FIT increased the probability of adopting new technologies, whereas an increase in capital costs did not affect the repowering of both instruments. Lie Dahl et al. carried out an analysis of the new turbines installed after repowering, compared to the existing turbines against the mortality of the birds in a wind power plant located in Norway [53]. Different wind turbine models and separation among them were considered, highlighting the importance not only of the decrease in the number of turbines, but also their location. The best repowered plant, with 30 turbines (5 MW), would reduce the collision risk of $32 \%$ compared to the current plant. A similar study was carried out by Oliver in Tarifa (Spain) [56]. He analyzed different alternatives from technical, economic, and environmental points of view to repower a wind power plant. The original wind power plant had a rated power of 23.4 MW with 78 turbines of $300 \mathrm{~kW}$. Two different alternatives were considered, using turbines with a rated power of $2 \mathrm{MW}$ : (i) keeping the same rated power of the plant, and (ii) increasing the rated power of the plant up to $35 \mathrm{MW}$. According to the results, both alternatives were economically viable and fulfilled the environmental regulations in the place. Recently, Grau et al. evaluated repowering in the case of Germany [71]. The methodology was based on technical, social, and economic factors. When the capacity of the turbines was increased, they needed a greater distance among them and, consequently, a larger area was required by the wind installations. Therefore, the distance constraints on urban areas could be affected. In total, 15 scenarios were designed; in the best case, an increase of $110 \%$ of the energy produced might be reached by 2040 , whereas the most negative case was $40 \%$. Subsequently, without a massive expansion, the contribution of wind energy to Germany's energy mix would diminish.

In 2016, Lantz et al. evaluated the evolution that should be carried out in power systems of the United States to provide 35\% of the end-use demand by 2050 with wind energy, considering technical and economic aspects [55]. They estimated that, each year, from 2014 to 2020, $8 \mathrm{GW}$ /year of wind energy should be installed; this value should be increased from 2021 to 2030, reaching 12 GW/year in such period; and from 2031 to 2050, $18 \mathrm{GW} /$ year should be installed. In all cases, both new additions and repowering were considered. Moreover, according to this study, 25 billion Euro/year would be needed for repowering in 2050. Similar studies were carried out in 2018 by Jung et al., for Germany [60], and by Ramírez et al., for Spain [61]. In the case of Germany, the aim of the work was to determine the best wind turbine locations to provide $40 \%$ of the overall electricity consumption. According to the results, a capacity of $100 \mathrm{GW}$ of wind energy (around 36,000 wind turbines) was enough to cover this target, which could be accomplished by around 2030 if the rate of wind energy expansion of Germany was maintained. Regarding the work focused on Spain, they analyzed the role of wind energy to meet the 2020 energy target of the country (i.e., cover at least $20 \%$ of gross final consumption of energy giving by RESs). In this work, both the repowering and commissioning of new wind power plants were assessed, combining them with the use of other RESs. Results showed that a minimum repowering level of $46 \%$ in combination with new wind power plants would be required to achieve the target. In 2020, Pryor et al. proposed theoretical scenarios to achieve a $20 \%$ electricity generation from wind energy in eastern USA [69]. These scenarios were based on repowering wind power plants (avoiding competition for land) to analyze their impact on the environment and the power system's efficiency. Two main scenarios were considered:

- $\quad$ Doubling scenario: wind turbines with rated capacity under 2.1 MW were repowered with $3 \mathrm{MW}$ turbines, and those with a rated power over $2.1 \mathrm{MW}$ were replaced with 5.2 MW turbines; 
- Quadrupling scenario: wind turbines with rated capacity under 2.1 MW were repowered with 8.2 MW turbines, and those with a rated power over 2.1 MW were replaced with 5.2 MW turbines.

Under these scenarios, the results showed that, with the doubling scenario, gross $\mathrm{CF}$ increased slightly, whereas for the quadrupling scenario, gross CF decreased due to the saturation of the wind resource in some areas. With regard to the environment, it was seen that their impact on near-surface climate properties at the regional scale was minor, even under the quadrupling scenario. In fact, authors affirm that 'climate impacts from wind turbines are modest compared to regional changes induced by historical changes in land cover and to the global temperature perturbation induced by use of coal to generate an equivalent amount of electricity'.

Villena et al. performed an extensive techno-economic analysis of a real repowered wind power plant in Galicia (Spain) [62]. The technical analysis considered the Annual Energy Production (AEP) and the Capacity Factor (CF) of the wind power plant. The economic analysis took into account the Present Value of Costs (PVC), the Cost of Energy (CoE), Net Present Value (NPV), Internal Rate of Return (IRR), Pay-Back Period (PBP) and the minimum Spot Price (SP min). Comparing the results between the old and the repowered wind power plant, the technical analysis showed that both indices doubled with the repowered wind power plant, and the economic analysis revealed that the repowered wind power plant was profitable. Other studies also focused on technical and economic factors in 2019. Michaud analyzed several hypotheses for repowering in France, such as dismantling and repowering all or just some wind turbines in the same location or others, in order to determine the economic viability [66]. The most viable project was to repower some wind turbines with new models in different locations. Vicente re-designed a wind power plant for a specific case study in Mexico: a new analysis of the wind potential was carried out to determine the best location, as well as the electrical infrastructure, the project was viable with a payback of almost 7 years [67]. Ziegler et al. analyzed the interaction among the technical, economic, and legal aspects for onshore wind turbine' life extension in Denmark, Germany, Spain, and the UK [63]. According to their study, such countries should start to face end-of-life solutions during 2020, and around 2000-4000 wind turbines would need, to be repowered or decommissioned to extend their lives. Moreover, as it is expected that wind technology in the near-future will progress slower than in recent decades, life-time extension is likely to become more attractive than repowering.

Machado et al., In 2019, linked technical factors (increase in nominal potential) and social factors (visual impact) to demonstrate the positive relationship between these factors in the design or relocation stage of wind turbines [65]. The methodology was based on the use of two key indices: Magnitude of Visual Effect (MVE) and the Spanish method (SPM), each of them with different indicators. The data were processed at the pixel level of each wind turbine with high resolution, to obtain the equivalent visual impact. The case study, developed in Spain, showed repowering increased capacity by $37 \%$ without visual effects. This methodology, with the assessment only of the visual impact, should be completed with the economic and environmental assessment. Similarly, in 2020, Kitzing et al. proposed a comprehensive and social perspective on repowering wind power plants based on a project-level analysis in Denmark, considering technical(capacity), political(pre-permit process), and social (noise emissions, visual impact, space in land) aspects [68]. According to their study, repowering was foreseen as an important technique to reach the maximum potential of wind energy, but involved complex technical, social, and political dimensions that must always be taken into account.

In 2021, two studies analyzed the technical-economic factors, Ceolin de Bona in Brazil [70] and Al Hamed with a case study in Denmark [72]. In the case of Brazil, $2 \mathrm{MW}$ is the nominal power limit per wind turbine to change to others of higher rated power, unless they are replaced by taller towers. Furthermore, 179 wind power plants have a power limit of lower than $2 \mathrm{MW}$, making them a very attractive repowering market. The economic viability is closely linked to a decrease in rates. Given the inexperience with repowering in 
Brazil, a study of the regulatory framework in other successful countries, such as Germany, Denmark, and the UK, is recommended. In the case of Denmark, three technical scenarios were proposed with the premise of keeping the same land available: (i) same capacity as the original, (ii) increasing capacity by $50 \%$, and (iii) doubling capacity. The results showed the economic viability of the first scenario. However, as the other scenarios must occupy the same space, the losses due to shadows were very high, causing a significant decrease in the electrical production. Indeed, good practices regarding the design of the location and orientation of wind turbines are of great importance to increase the productivity of the wind power plant [73].

\subsection{Single-Category Analysis}

Table 3 summarizes contributions where only a single category is included for onshore wind power plant repowering strategies.

Table 3. Contributions with a single category in onshore wind repowering methodologies. Period (2000-2021).

\begin{tabular}{|c|c|c|c|c|c|c|c|}
\hline Ref. & Year & Technical & Economic & $\begin{array}{l}\text { Categories } \\
\text { Environmental }\end{array}$ & Political & Social & Region \\
\hline [74] & 2006 & & & $\mathrm{X}$ & & & Germany \\
\hline [75] & 2009 & & & $x$ & & & USA \\
\hline [76] & 2010 & & $x$ & & & & India \\
\hline [77] & 2010 & & & $x$ & & & USA \\
\hline [78] & 2012 & $x$ & & & & & India \\
\hline [79] & 2012 & & & $x$ & & & No case study \\
\hline [80] & 2013 & $x$ & & & & & India \\
\hline [81] & 2013 & & & & $x$ & & Spain \\
\hline [82] & 2014 & & & $x$ & & & Belgium \\
\hline [83] & 2014 & & & $x$ & & & No case study \\
\hline [84] & 2016 & & & $x$ & & & No case study \\
\hline [85] & 2016 & & $x$ & & & & Spain \\
\hline [86] & 2016 & & & $x$ & & & Italy \\
\hline [87] & 2016 & $x$ & & & & & Spain \\
\hline [88] & 2017 & $x$ & & & & & Spain \\
\hline [89] & 2017 & & & $x$ & & & USA \\
\hline [90] & 2017 & $x$ & & & & & Tunisia \\
\hline [91] & 2018 & $x$ & & & & & Tunisia \\
\hline [92] & 2018 & & & $x$ & & & No case study \\
\hline [93] & 2018 & & & $x$ & & & Worldwide \\
\hline [94] & 2020 & $x$ & & & & & India \\
\hline [95] & 2020 & & & & $x$ & & India \\
\hline [96] & 2020 & & $x$ & & & & Germany \\
\hline [97] & 2020 & & & & $x$ & & $\mathrm{DE}, \mathrm{CN}$ \\
\hline [98] & 2020 & $x$ & & & & & Pakistan \\
\hline [99] & 2020 & $x$ & & & & & No case study \\
\hline [100] & 2020 & & & $x$ & & & USA \\
\hline [101] & 2020 & $x$ & & & & & Germany \\
\hline [102] & 2020 & & & $x$ & & & Germany \\
\hline [103] & 2020 & & & $x$ & & & USA \\
\hline
\end{tabular}

In 2012, Sen et al. analyzed the repowering potential of three regions of India (Tamilnadu, Gujarat, and Andhra Pradesh) [78]. Considering the wind power plants installed until 1997 with more than two wind turbines of nominal power under $500 \mathrm{~kW}$, in the regions under analysis, 519, 72, and 43 MW could be repowered, respectively. In 2013, Nivedh et al. carried out another technical repowering analysis of a wind power plant in 
India [80]. The results were very positive, doubling the $\mathrm{CP}$ and increasing $(24 \%)$ the Plant Load Factor (PLF). In 2020, Kadhirvel et al. studied the repowering of old wind turbines in India according to different rated powers of new turbines [94]. By increasing the capacity in the repowered wind power plant by between 1.25 and 3 times, the overall electricity generation could be increased by 11 times. In 2016, Méndez and López proposed a new methodology to evaluate the limits of repowering and/or commissioning of new RESs in an isolated power system (Gran Canaria Island, Spain) [87]. In this study, both the repowering of wind and solar installations was considered. According to the results, if more than $100 \mathrm{MW}$ of RESs were installed, the power system could not operate in a secure manner; in fact, there would be frequent events of grid instability. In 2017, Santos-Alamillos et al. applied Markowitz's mean variance (MV) portfolio optimization theory, with the aim of exploring repowering alternatives at the national level in Spain [88]. They proposed three scenarios: (i) ideal repowering (total dismantling and redistribution of energy capacity in a more time-consuming way), (ii) full repowering (total dismantling but limited to the installation capacity of each region), and (iii) partial repowering (maintaining current capacity). They concluded that, according to the configuration of the optimization model, keeping the level of energy productivity constant could reduce up to $31 \%$ the hourly fluctuations in the supply, and more efficient combinations of wind turbine relocation could be obtained with increased productivity, which could be improved up to $55 \%$. Similarly, Karoui et al. also focused on the impact of repowering a wind power plant of Tunisia on the power system stability [91]. The initial wind power plant was based on type 1 wind turbines (i.e., squirrel cage induction generators), and the repowered one used type 3 turbines (i.e., doubly fed induction generators). The number of wind turbines was reduced by four times (from 32 to 8 ), whereas the power installed and the annual production substantially increased (by 2.5 and 4.1 times, respectively). Moreover, the grid stability was improved with the new turbines, being more suitable to power grid requirements (grid code). In 2020, Lacal et al. analyzed the empirical data on repowered wind power plants in Denmark and Germany, determining the evolution between the previous wind turbines and the new installed ones [101]. They found the following:

- New wind turbines were twice as high as the previous ones;

- The rotor diameter of new wind turbines was three times larger than the previous blades, consequently having a swept area nine times larger;

- Nominal power of new wind turbines was around six times the power of the initial turbines.

All these changes led to an electricity generation that was increased by nine times compared to the old turbines. Other authors have focused on partial repowering. In 2020, Syed et al. presented a methodology for the partial repowering of wind power plants, considering the reduction in generation due to the wake interactions inside the wind power plant (and with neighboring wind power plants), using a case study in Jhimpir (Pakistan) [98]. The partial repowering consisted of modifying the hub height of the turbines. Moreover, the methodology demonstrated the need to consider the wake interactions among wind turbines inside the power plant, and with nearby wind power plants as well. Hu et al. proposed a repowering approach to tubular steel wind turbine towers [99]. This solution was numerically carried out with a finite element software (ABAQUS).

In recent decades, only three contributions have been focused on economic factors alone. In 2010, Goyal [76] focused on financial highlights of onshore wind repowering in India. The main factors affecting the IRR of the repowering project are the capital costs and the cumulative utilization factor of the places. With regard to the capital costs, Goyal found that although the capital costs were high, the IRR was still more attractive than for greenfield projects. On the other hand, the cumulative utilization factor seems to have a greater effect on the IRR of the project. In fact, they determined that an increase of $1 \%$ of the cumulative utilization factor causes an increase in IRR of $1.6 \%$. In 2016, Castro et al. proposed a methodology to determine the main costs and the feasibility of 
repowering onshore wind farms, considering Galicia (Spain) as a case study [85]. The methodology combined two methods, considering the following: (i) Spanish legislation for repowering and (ii) different types of wind turbines. A total of 9 alternatives for repowering were defined. These alternatives were then compared considering: non-financing (all the investment is supported by the enterprise) and financing (external investor, probably a bank) in terms of the Net Present Value (NPV), Internal Rate of Return (IRR), and Pay-Back Period (PBP). Their analysis concluded that NPV is not greatly influenced if the project has (or not) external financing, whereas both IRR and PBP are. In fact, all the alternatives have a higher IRR and a lower PBP value when the project has external financing. Based on these economic indicators, the optimal repowering option was obtained. Recently, in 2020, Fuchs et al. examined the economic viability of investments for repowering older wind power plants in Mecklenburg-Western Pomerania (Germany) [96]. That study resulted in a high profitability of the investment. Moreover, a risk analysis was accomplished, showing that the economic viability of repowering wind power plants depends on the feed-in tariff, although it would still be cost-effective if the feed-in tariff reduced to $40 € / \mathrm{MWh}$.

The concern about the negative impact on birds and bats with the repowering of wind farms dates back to 2006, when Hermann Hotker [74] carried out a detailed study in Germany. He concluded that the evaluation should be different according to the variety of bird species. In this line of mortality analysis according to species, Smallwood et al. in 2009 (California-USA) carried out a Digital Elevation Model (DEM) of collision hazardmaps and hazard ratings of wind turbines to guide careful repowering to modern turbines [75]. In 2010, Smallwood et al. studied the impacts of birds and bats with wind turbines in California (USA) [77]. According to this study, wind turbines that have a low capacity factor cause more fatalities/GWh. Consequently, the impacts of birds and bats with wind turbines could be reduced by repowering old turbines with more modern and efficient ones. Similar results were obtained in 2014 by Everaert, analyzing the impact of bird collisions in Flanders (Belgium) [82]. He proposed repowering wind power plants with larger wind turbines-and, subsequently, larger rated power, but fewer turbines may decrease the impacts of birds and, thus, total mortality in some regions. Similarly, other authors affirmed that repowering wind power plants with fewer but larger turbines can reduce the mortality of birds impacts $[83,84,89,93,102]$. In contrast to previous studies, in 2016, Ferri et al. analyzed the impact of a repowered wind power plant located in central Italy on bats [86]. They considered not only the mortality of bats due to collision, but also the habitat changes and disturbances. The results showed that some bats could also be sensitive to repowering. Moreover, they could suffer apparent stress due to the repowering processes. A recent quantitative study published in 2021 contradicts the results of previous contributions. According to Huso et al., if the same energy is generated after repowering smaller wind turbines with larger machines, slight differences in wildlife mortality will occur [100].

From the environmental impact point of view, in 2012, Zimmerman proposed a new methodology to identify the environmentally preferable option to repower wind power plants using the specific energy demand as an indicator [79]. The proposed method provided different repowering options at a particular site in terms of their specific energy demand. In 2018, Martínez et al. analyzed the environmental impact and benefits of a wind power plant repowering process though a life cycle assessment model [92]. Wind turbines had an important impact on the repowering process, with values of $2.43 \times 10^{7} \mathrm{~kg} \mathrm{CO}$,eq; the substation and electrical lines $\left(5.14 \times 10^{5} \mathrm{~kg} \mathrm{CO}_{2, e q}\right)$ also had a severe impact. However, these impacts are balanced by the increase in the electrical generation derived from wind energy, reducing the $\mathrm{kg} \mathrm{CO}_{2, e q}$ with a value of $-9.03 \times 10^{8} \mathrm{~kg} \mathrm{CO}_{2, e q}$. Therefore, repowering old wind power plants (low rated power wind turbines) with new turbines with a higher rated power is an interesting option from an environmental point of view. Recently, in 2020, Szumilas-Kowalczyk et al. focused on the visual impact of old wind power plants in California (USA) [103]. In fact, wind power plants modify the landscapes where the wind turbines are installed, having an aesthetic impact on such areas. According to this 
study, there are four options for the transformation of old wind power plants: (i) full decommissioning, (ii) constant repowering, (iii) repowering preceded by full decommissioning, and (iv) transition towards a tourist attraction. To reduce the landscape impact, among the two strategies related to repowering, repowering preceded by full decommissioning is better than constant repowering, as constant repowering could involve different wind turbine sizes and styles.

With regard to the political analysis category of repowering onshore wind power plants, it is a necessity to establish a reliable and solid regulatory framework to increase the opportunities for expansion in wind power (new installations or repowering). Rodríguez et al. focused on 2013 on the case of Spain [81]. The supportive state legislation, combined with the launching of Spanish manufacturing of turbines and the attraction of investors caused the massive development of wind energy by 2010 in that country. In 2013, the Royal Decree 661/2007 regulated the wind power plants repowering in Spain, and only those installations fulfilling several conditions (i.e., final registration date, installed power, supply continuity during voltage dips, and power increase after repowering) could receive a premium upgrade. Moreover, it concluded that $1 / 4$ of the wind power plants installed by then could not withstand power outages, subsequently creating an excellent opportunity for the wind repowering market. Recently, in 2020, Das et al. analyzed the main factors that were influencing the onshore wind energy deployment in India, being the presence of repowering policy one of them [95]. However, in that country, only four states have such type of politics. Consequently, these states are more preferable to repower wind power plants. Guan [97] carried out a comparison between Germany and China considering administrative, legislative, policy, and planning aspects for onshore wind power plants. The main difference between these two countries is that Germany is facing the challenge of how to transfer to the second generation of wind turbines, whereas China is still establishing its first generation. From this point, China can consider the different problems that Germany has already confronted related to repowering issue, and deal with them in a suitable way for China. In fact, one of the main issues that Germany has faced, is the difference between the current height of wind turbines, in contrast to those installed more than 20 years ago. As the new wind turbines can reach up to $200 \mathrm{~m}$ height, current planning procedures need to be amended, or new ones created, to ease the repowering of older wind power plants with taller wind turbines.

Finally, regarding the social analysis category, no repowering studies were found in the specific literature. However, an interesting study focused on surveys to analyze the attitude towards wind energy carried out in Spain and Poland reveals that there are several disagreements in relation to the aesthetics of wind turbines and the perceived cost of wind power [104].

\section{Repowering Strategies for Offshore Wind Power Plants}

In this section, different contributions related to the repowering of offshore wind power plants are discussed and reviewed. In Table 4, such works focused on this topic are summarized. In 2016, Bezbradica et al. [105] proposed a multi-criteria decision analysis based on the PROMETHEE II method. This methodology was applied to the Bockstigen offshore wind power plant (Sweden), considering 14 criteria and seven stakeholders, and analyzing four repowering scenarios. According to the results, one of the four scenarios had a high possibility of consensus between stakeholders, making it the most likely to succeed. In 2017, Hou et al. focused on technical and economic analysis for repowering offshore wind power plants [106]. An optimization methodology was proposed as an alternative to dismantling such facilities. Two scenarios were considered: (i) the replacement of the turbines by the same model; and (ii) the replacement by a newer different model. The final evaluation focused on the LCoE, finding that the second scenario had a lower value $(10.43 \%)$. A similar study was carried out by He et al. several years later. They compared the LCoE and electricity generation of repowering offshore wind power plants (at year 15) to decommissioning them after 20 years or after having a lifetime extension 
of 5 years (decommissioning after 25 years) [107]. Both fixed and floating foundations were considered. According to the results, repowering offshore wind power plants had great potential. In fact, a severe increase in the electricity generations was obtained, in addition to a reduction in the LCoE. Comparing the two types of foundations, greater $\mathrm{LCoE}$ reductions were found for floating foundations.

Table 4. Papers with offshore wind repowering methodologies. Period (2000-2021).

\begin{tabular}{|c|c|c|c|c|c|c|c|}
\hline Ref. & Year & Technical & Economic & $\begin{array}{l}\text { Categories } \\
\text { Environmental }\end{array}$ & Political & Social & Region \\
\hline [105] & 2016 & $\mathrm{X}$ & $x$ & $x$ & & $x$ & No case study \\
\hline [106] & 2017 & $x$ & $X$ & & & & Denmark \\
\hline [108] & 2019 & $x$ & $x$ & & & & No case study \\
\hline [109] & 2019 & $x$ & $x$ & & & & Denmark \\
\hline [107] & 2020 & $x$ & $x$ & & & & No case study \\
\hline [110] & 2020 & & $X$ & $\mathrm{X}$ & & & China \\
\hline [111] & 2020 & $x$ & $x$ & & & & China \\
\hline [112] & 2021 & $x$ & $x$ & & & & UK \\
\hline
\end{tabular}

In 2019, two studies with technical and economic multifactorial analysis were developed for specific case studies in Denmark [108] and China [109], respectively. In the case of Denmark, Bergval used RETScreen software to estimate the annual energy production. The LCoE was considered the optimization indicator, and a sensitivity analysis was also carried out to determine the main indicators affecting the LCoE. The best of the scenarios had an $\mathrm{LCoE}$ of 57.18 \$/MWh, and both CAPEX and AEP were the parameters that most affect the LCoE. For China, new models of greater capacity were proposed, with improvements in the turbine location. In this way, a reduction in the wake effect was obtained, together with the use of the maximum wind potential. Considering the offshore wind power plant in Sha Chau (China), the value of the LCoE was 118 \$ MWh. From these works, the difference between the results of the LCoE is noticeable. Indeed, and according to the IRENA 2018 report [113], the LCoE was approximately 139 \$/MWh in that year. In 2020, Boylan focused on how to select foundations for offshore wind power plants [110]. The study aimed to minimize the LCoE and environmental impacts when such foundations were repowered. The Scotland's North Sea (UK) was considered as a case study. Recently, in 2021, Jadali et al. evaluated the best option between the dismantling of offshore wind plants and the repowering through a technical-economic analysis [112]. The methodology was applied to a hypothetical case study, with repowering being the best option, reducing the LCoE by $35 \%$. Zuo et al. [111] proposed a new design for the collector system to repower and expand offshore wind power plants, aiming to link a repowered wind power plant and a new one. To overcome this problem, a cross-substation incorporation and a radial design was considered. Results showed that this design obtained a reduced investment cost in comparison to traditional designs (i.e., ring and radial), at a time when a high reliability level is maintained in the long-term assessment.

\section{Results and Discussion}

The scientific community began to investigate the repowering of wind power plants from the approach of the end of their useful life of the first wind installations. In turn, the growth rate of these scientific contributions has evolved increasingly in parallel to the installed capacity increase. Works focused on onshore wind installations repowering began around 2000-20 years after the commissioning of the first onshore wind power plant. Today, 72 have studies covered until the first quarter of year 2021. The first offshore wind power plant began generating emission-free electricity in 1991 [114]. In 2016, 25 years later, the first offshore wind repowering scientific work was published. To date, eight studies have directly investigated the subject; see Figure 3 [115]. At the European level, the 
repowering market is highly evident. Figure 4 shows the annual number of 20-year-old wind turbines in Germany, Denmark, Spain, and the United Kingdom and, thus, the end of their useful life [116]. The next decade for these countries is marked by repowering actions-an average of 3000 wind turbines per year will need repowering. Subsequently, the contribution of the wind sector to the electricity grid reaches the European objectivesthe EU should cover at least $32 \%$ of its total energy needs with renewable energies by 2030 [117].

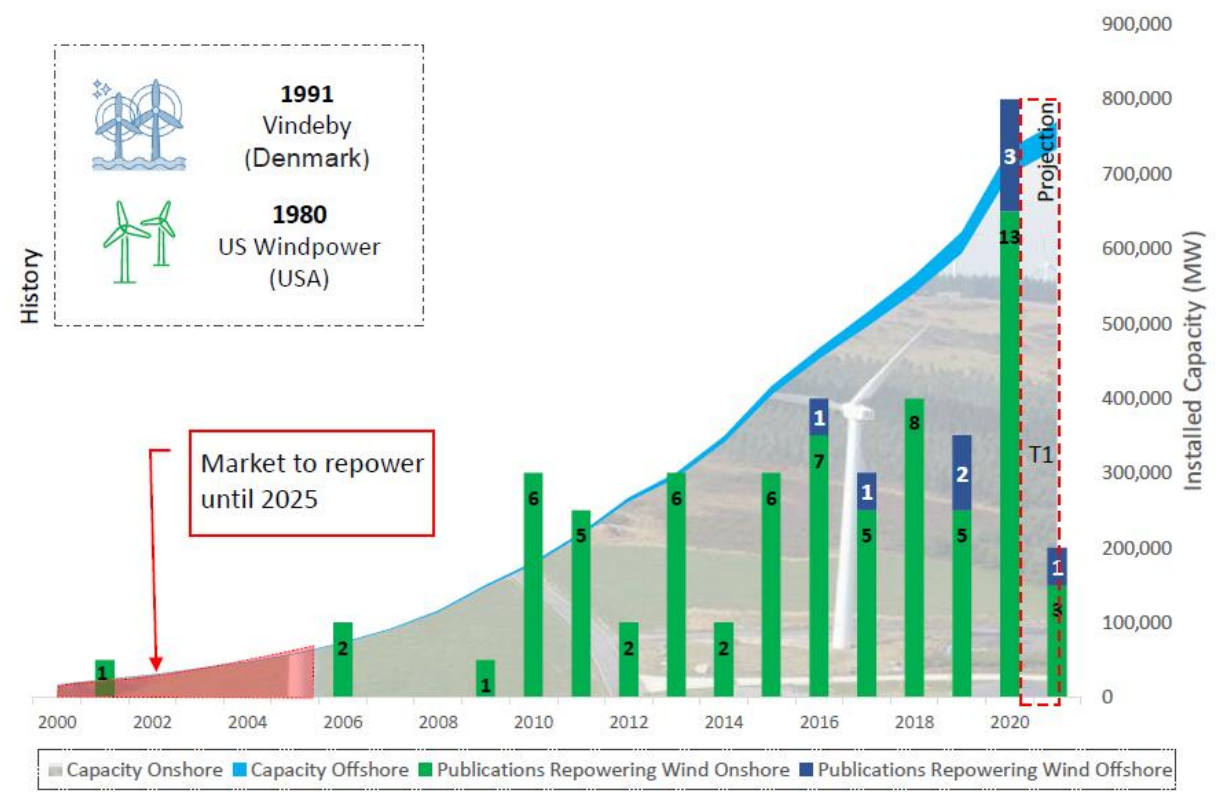

Figure 3. 2000-2021 Evolution of installed capacity vs. scientific publications (source: own elaboration).

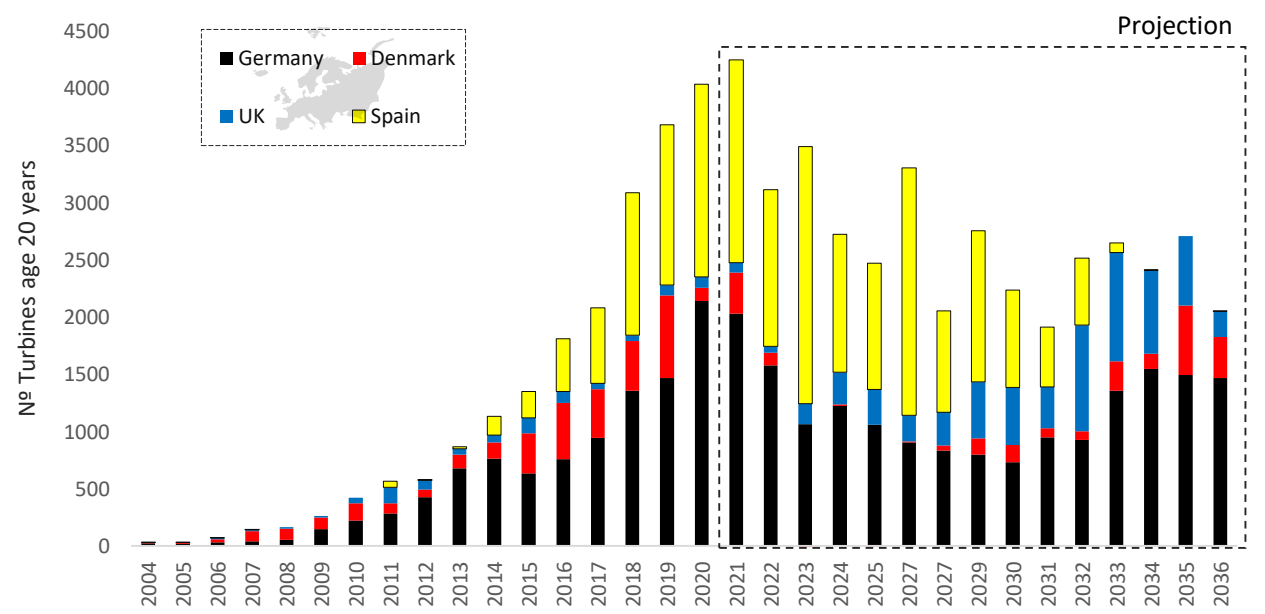

Figure 4. Number of turbines age 20 years. Germany, Denmark, UK, and Spain (source: own elaboration).

In line with the creation of technology and the need for wind repowering, during the period $2000-2021,90 \%$ of the publications were related to onshore installations, and the rest of them, to offshore installations; see Figure 5. Furthermore, more than $18 \%$ (14 papers) of all studies involve Germany as a case study. This is to be expected, as Germany is a pioneer in onshore and offshore wind technologies, promoting a wide range of policies in favor of climate change and energy transition [118]. In the future, the scenario of repowering onshore wind plants since 2003 is practically a symmetry of the scenario of new installations in the period 1990-2020. Most of the new installed capacity will be the replacement of small wind turbines with new technology with higher nominal power [63]; see Figure 6. 
Spain and the United States (USA), leading countries in electricity generation from onshore wind power plants and with a view to the deployment of offshore wind [73], are the next two countries that have been case studies for repowering analysis, with $15 \%$ (12 works) and $11 \%$ (nine works) of total publications, respectively. Denmark, a country committed to the wind sector [119], and India, with 9\% (7 works) of the total publications, are depicted in Figure 5. For detailed data, see Table 5.

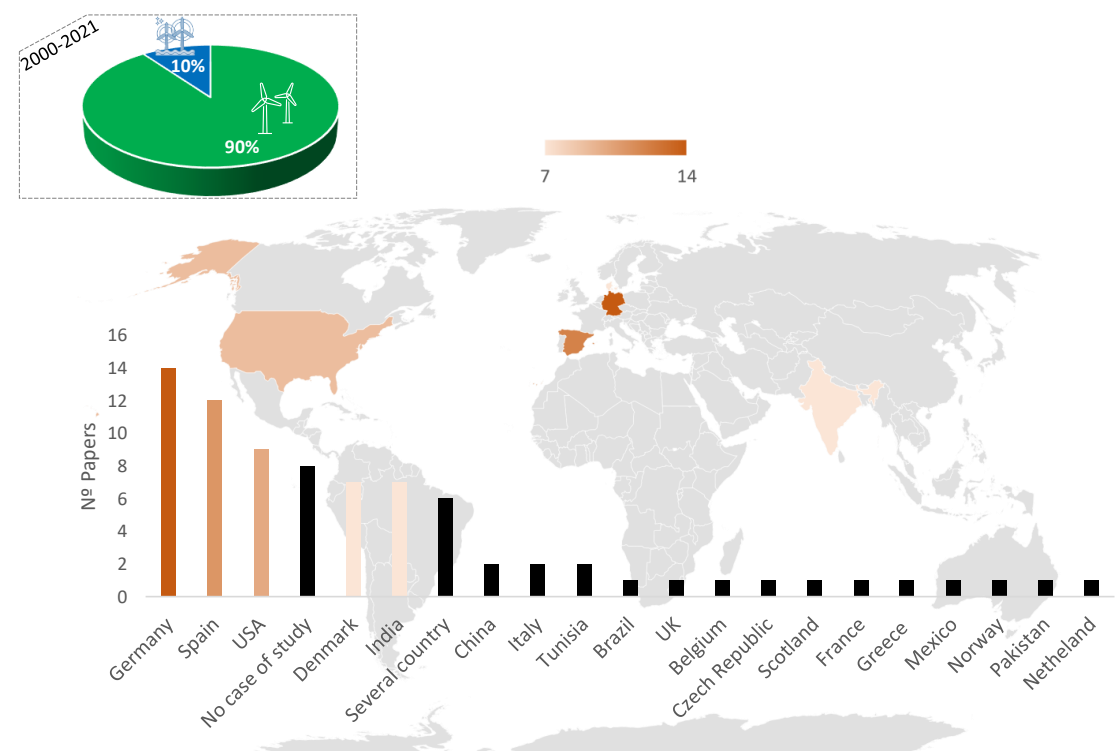

Figure 5. Scientific publications by country (2000-2021).

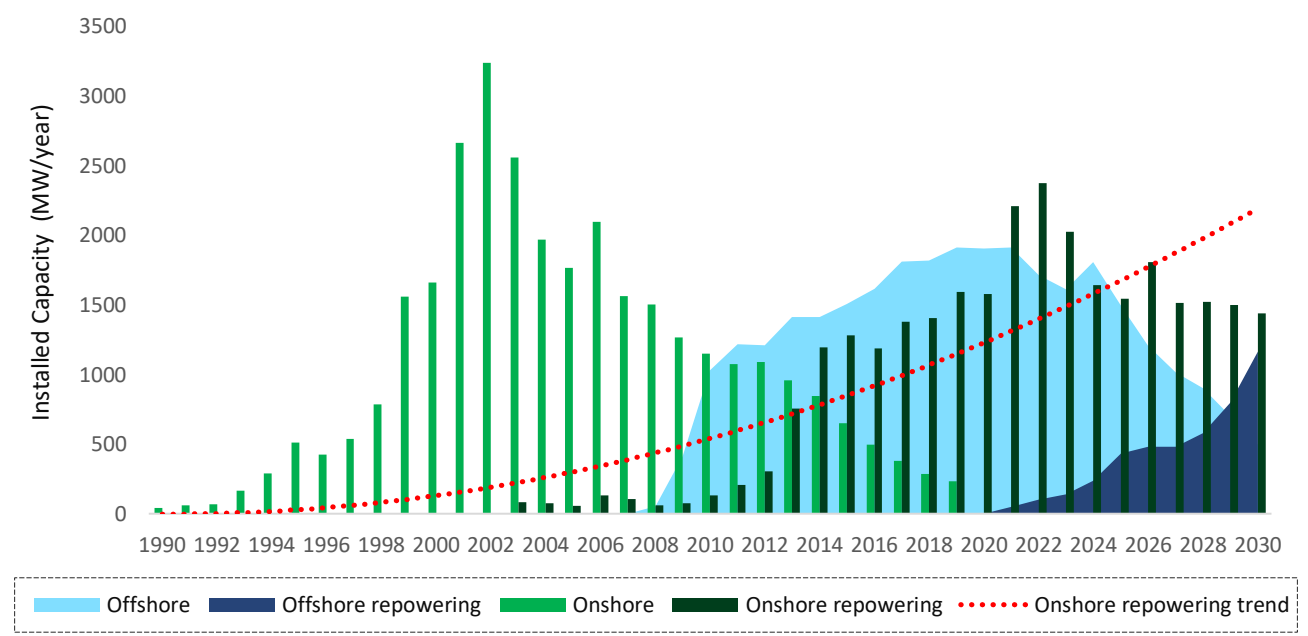

Figure 6. Annual installed capacity versus repowering market. Germany (source: own elaboration).

In order to carry out an onshore or offshore wind repowering study, the authors of such works consider different categories, which may be technical, economic, environmental, political, and social. Regarding the technical factor, they mainly analyze, on the one hand, the technology-nominal power of the power plant, new capacity factor, losses due to the wake effect, and so forth-and, on the other hand, the integration into the electricity grid based on possible changes in infrastructure, as well as the use of existing foundations, and an analysis of the wind potential at the new height of the wind turbines. The economic factor involves a new financial economic analysis with different items, such as CAPEX (capital expenditure), OPEX (operational expenditures), and the feasibility results: NPV (net present value), IRR (internal rate of return), and PBP (payback period, that is, recovery period in years). Environmental factors are fundamentally related to the protection of 
the flora and fauna of the places where a wind power plant is repowered, or where it will be repowered. Social factors include visual impact, noise levels, new calculations of distances to urban areas, roads, and so forth. Finally, political factors are based on policy initiatives and incentives established in favor of RESs. These incentives could be received in compensation for producing electricity from RESs and taxes involved in the activity. In the repowering works focused on onshore wind power plants, $58 \%$ of the authors include technical factor in their methodologies (44 papers), whereas $43 \%$ include economic factor (33 studies). The social factor is the least used, with $12 \%$, whereas the environmental and political categories range between 30 and $36 \%$. Despite the few articles related to repowering offshore wind power plants, the economic point of view seems to be the most important one, as $100 \%$ of those works consider such factor. Moreover, the authors would like to highlight the non-application of political factors in these types of facilities. In addition, in the case of offshore repowering, 100\% of the authors include several factors (multifactorial analysis), in contrast to onshore repowering, where only $68 \%$ of the authors carry out a multifactorial analysis and the rest use a single factor; see Figure 7. Furthermore, both technical and economic factors are applied simultaneously in 34 studies, almost $43 \%$. Although there are only a few works focused on political factors, the influence of financial incentives and improvements in regulatory hurdles are notable factors in accelerating investment in repowering. The factors analyzed by the authors within the social category do not include the relationship between employability and repowering. A wind project has more human resources in the execution stage than in the exploitation stage, but what implications would repowering have on the exploitation stage in terms of employability? Would the presence of fewer wind turbines imply a reduction of human resources? This social factor is very important to include in these studies. Indeed, there are factors of greater weight than others. From a technical point of view, a repowering project is practically the same as a wind power plant project with some minor differences. The lack of research involving a methodology with factors of all categories shows that repowering is a complex problem. The authors of this review suggest the use of multicriteria evaluation methods (MCDM) in repowering projects, including multifactorial methodologies in order to optimize the project.
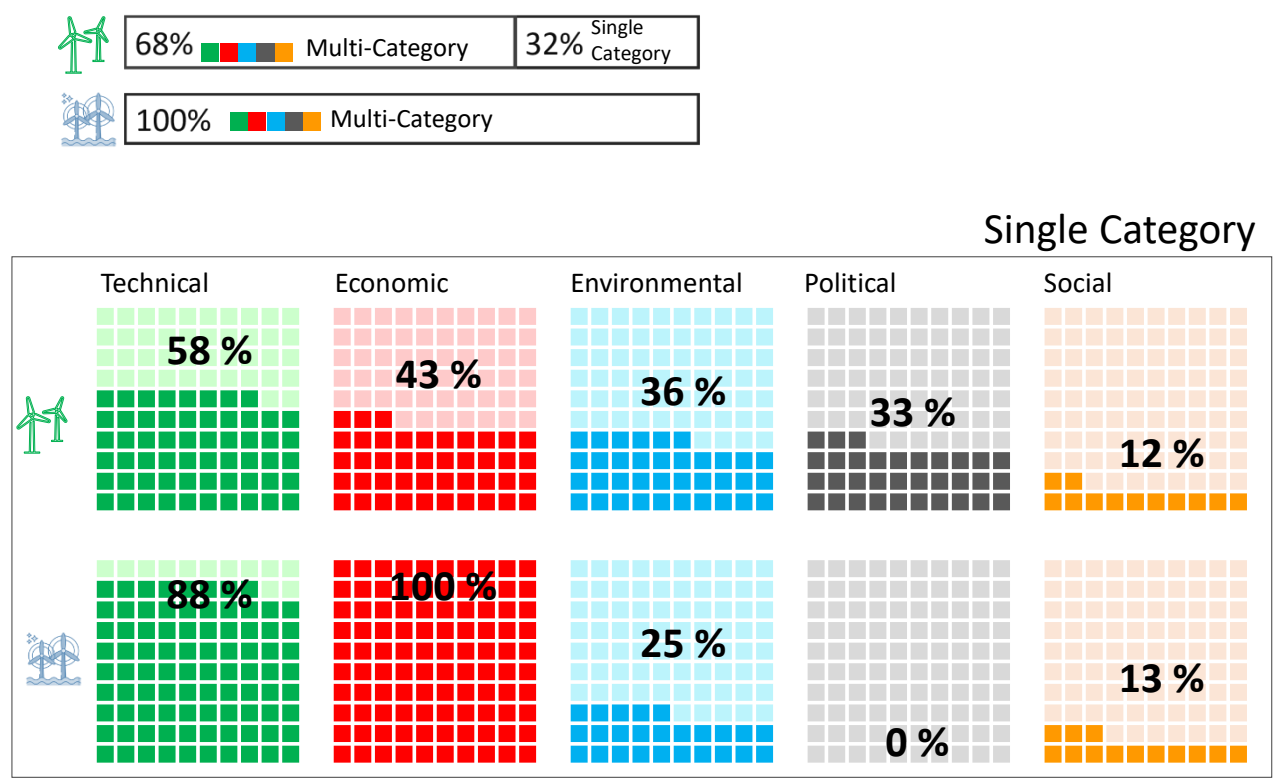

Figure 7. Analysis by categories. First line: Onshore wind power plants. Second line: Offshore wind power plants. 
Table 5. Revised papers by country and technology. Period (2000-2021).

\begin{tabular}{ccc}
\hline Country & Onshore & Offshore \\
\hline Germany & {$[38,39,44-46,54,58,60,64,71,96,101,102]$} & - \\
Spain & {$[41,49,51,56,61,62,65,81,85,87,88]$} & - \\
USA & {$[48,55,69,75,77,89,100,103]$} & - \\
No case of study & {$[79,83,84,92,99]$} & {$[105,107,110]$} \\
Denmark & {$[37,40,43,68,72]$} & {$[106,108]$} \\
India & {$[52,57,76,78,80,94,95]$} & - \\
Several countries & {$[42,63,93,97]$} & - \\
Italy & {$[59,86]$} & - \\
Tunisia & {$[90,91]$} & - \\
China & - & {$[109,111]$} \\
Netherlands & {$[36]$} & - \\
Greece & {$[47]$} & - \\
Czech Republic & {$[50]$} & - \\
Norway & {$[53]$} & - \\
France & {$[66]$} & - \\
Mexico & {$[67]$} & - \\
Brazil & {$[70]$} & - \\
Belgium & {$[82]$} & - \\
Pakistan & {$[98]$} & - \\
UK & - & \\
\hline
\end{tabular}

\section{Conclusions}

This paper presents a review of different wind repowering strategies, identifying the most relevant categories to be considered for decision-making purposes. Technical, economic, environmental, social, and political categories are defined and analyzed, including different factors. Onshore and offshore wind power plant repowering strategies are considered for this analysis, from a multi-category and uni-category perspective. A total of 1880 contributions were initially identified. After an initial revision process, 80 contributions were selected for the period 2000-2021. In this way, $90 \%$ of those contributions are related to onshore installations and the rest of them to offshore power plants. This severe difference between onshore and offshore repowering studies is a consequence of the age of onshore wind power plants, in contrast to the quite recent interest and start-up of offshore installations. Of the studies carried out for onshore power plants, $68 \%$ consider a multi-category analysis, whereas all the analysis focused on offshore repowering proposes a multi-category analysis. By regions, most case studies are conducted in Europe and America. Specifically, several installations located in Germany, Spain, the USA, and Denmark have been considered, which is in line with (i), the age of the wind power plants, and (ii), the promotion and integration of wind energy in such countries. Indeed, these studies reflect the need for repowering in those installations which are old and located in the best windy places. In repowering works focused on onshore wind power plants, $58 \%$ of the authors included the technical category in their methodologies (44 works), and $43 \%$ include economic factors (33 works). The social factor is the least used, with $12 \%$, and the environmental and political factors range between $30 \%$ and $36 \%$, respectively. Regarding offshore repowering, the economy is identified as the most important factor, probably due to the higher installation cost of these power plants. As only a few contributions are focused on offshore power plants, it is necessary to propose more repowering strategies for these installations. Finally, the authors would like to emphasize that new multifactorial analyses, including the five categories proposed in this review, are needed to propose a full overview of the benefits (or not) of repowering wind power plants. 
Author Contributions: Conceptualization, I.C.G.-G. and M.S.G.-C.; methodology, I.C.G.-G.; formal analysis, A.F.-G.; resources, I.C.G.-G. and M.S.G.-C.; data curation, A.F.-G.; writing-original draft preparation, I.C.G.-G. and A.F.-G.; writing-review and editing, A.M.-G. and M.S.G.-C.; supervision, A.M.-G. All authors have read and agreed to the published version of the manuscript.

Funding: This research received no external funding.

Institutional Review Board Statement: Not applicable.

Informed Consent Statement: Not applicable.

Data Availability Statement: The data presented in this study are available on request from the corresponding author.

Acknowledgments: Ana Fernández-Guillamón would like to thank Spanish SEPE (Spanish National Unemployment System) for its funding support.

Conflicts of Interest: The authors declare no conflicts of interest.

\section{Abbreviations}

The following abbreviations are used in this manuscript:

$\begin{array}{ll}\text { AEP } & \text { Annual Energy Production } \\ \text { ALCoG } & \text { Annual Levelized Cost of Generation } \\ \text { CAPEX } & \text { Capital Expenditure } \\ \text { CF } & \text { Capacity Factor } \\ \text { CoE } & \text { Cost of Energy } \\ \text { ESS } & \text { Energy Storage System } \\ \text { FIT } & \text { Feed-In Tariff } \\ \text { GIS } & \text { Geographical Information System } \\ \text { IRR } & \text { Internal Rate of Return } \\ \text { LCoE } & \text { Levelized Cost of Energy } \\ \text { NPV } & \text { Net Present Value } \\ \text { NPRV } & \text { Net Present Repowering Value } \\ \text { NREL } & \text { National Renewable Energy Laboratory } \\ \text { PBP } & \text { Pay-Back Period } \\ \text { PCC } & \text { Point of Common-Coupling } \\ \text { PRISMA } & \text { Preferred Reporting Items for Systematic Reviews and Meta-Analyses } \\ \text { OPEX } & \text { Operational Expenditure } \\ \text { PVC } & \text { Present Value of Costs } \\ \text { RES } & \text { Renewable Energy Sources } \\ \text { ROC } & \text { Renewable Obligation Certificate } \\ \text { SP min } & \text { Minimum Spot Price } \\ \text { USA } & \text { United States }\end{array}$

\section{References}

1. Tafarte, P.; Das, S.; Eichhorn, M.; Thrän, D. Small adaptations, big impacts: Options for an optimized mix of variable renewable energy sources. Energy 2014, 72, 80-92. [CrossRef]

2. Fernández-Guillamón, A.; Villena-Lapaz, J.; Vigueras-Rodríguez, A.; García-Sánchez, T.; Molina-García, Á. An adaptive frequency strategy for variable speed wind turbines: Application To high wind integration into power systems. Energies 2018, 11, 1436. [CrossRef]

3. Zhong, M.; Bazilian, M.D. Contours of the energy transition: Investment by international oil and gas companies in renewable energy. Electr. J. 2018, 31, 82-91. [CrossRef]

4. Alola, A.A.; Yalçiner, K.; Alola, U.V.; Akadiri, S.S. The role of renewable energy, immigration and real income in environmental sustainability target. Evidence from Europe largest states. Sci. Total Environ. 2019, 674, 307-315. [CrossRef] [PubMed]

5. Wang, D.D.; Sueyoshi, T. Climate change mitigation targets set by global firms: Overview and implications for renewable energy. Renew. Sustain. Energy Rev. 2018, 94, 386-398. [CrossRef]

6. Ram, M.; Bogdanov, D.; Aghahosseini, A.; Oyewo, S.; Gulagi, A.; Child, M.; Fell, H.J.; Breyer, C. Global Energy System Based on 100\% Renewable Energy-Power Sector; Lappeenranta University of Technology and Energy Watch Group: Lappeenranta, Finland, 2017. 
7. Renewable Energy Prospects for the European Union; Technical Report; International Renewable Energy Agency (IRENA), European Commission (EC): Abu Dhabi, United Arab Emirates, 2018; ISBN 978-92-9260-007-5. Available online: http:/ / www.irena.org/ publications (accessed on 5 July 2021).

8. Ten-Year Network Development Plans (TYNDPs) 2020—Scenario Report. Technical Report, ENTSO-E and ENTSOG, 2020. Available online: https:/ /2020.entsos-tyndp-scenarios.eu/ (accessed on 5 July 2021).

9. Saint Akadiri, S.; Alola, A.A.; Akadiri, A.C.; Alola, U.V. Renewable energy consumption in EU-28 countries: Policy toward pollution mitigation and economic sustainability. Energy Policy 2019, 132, 803-810. [CrossRef]

10. Ediger, V.S. An integrated review and analysis of multi-energy transition from fossil fuels to renewables. Energy Procedia 2019, 156, 2-6. [CrossRef]

11. Eroglu, H. Effects of COVID-19 outbreak on environment and renewable energy sector. Environ. Dev. Sustain. 2021, 23, 4782-4790. [CrossRef]

12. Barbier, E.B.; Burgess, J.C. Sustainability and development after COVID-19. World Dev. 2020, 135, 105082. [CrossRef]

13. Madurai Elavarasan, R.; Pugazhendhi, R.; Jamal, T.; Dyduch, J.; Arif, M.; Manoj Kumar, N.; Shafiullah, G.; Chopra, S.S.; Nadarajah, M. Envisioning the UN Sustainable Development Goals (SDGs) through the lens of energy sustainability (SDG 7) in the post-COVID-19 world. Appl. Energy 2021, 292, 116665. [CrossRef]

14. Asantewaa-Owusu, P.; Asumadu-Sarkodie, S. A review of renewable energy sources, sustainability issues and climate change mitigation. Cogent Eng. 2016, 3, 1167990. [CrossRef]

15. Fleta-Asín, J.; Muñoz, F. Renewable energy public-private partnerships in developing countries: Determinants of private investment. Sustain. Dev. 2021, 29, 653-670. [CrossRef]

16. Ellabban, O.; Abu-Rub, H.; Blaabjerg, F. Renewable energy resources: Current status, future prospects and their enabling technology. Renew. Sustain. Energy Rev. 2014, 39, 748-764. [CrossRef]

17. Fernández-Guillamón, A.; Das, K.; Cutululis, N.A.; Molina-García, Á. Offshore wind power integration into future power systems: Overview and trends. J. Mar. Sci. Eng. 2019, 7, 399. [CrossRef]

18. Muñoz-Benavente, I.; Hansen, A.D.; Gómez-Lázaro, E.; García-Sánchez, T.; Fernández-Guillamón, A.; Molina-García, Á. Impact of combined demand-response and wind power plant participation in frequency control for multi-area power systems. Energies 2019, 12, 1687. [CrossRef]

19. Lu, Y.; Khan, Z.A.; Alvarez-Alvarado, M.S.; Zhang, Y.; Huang, Z.; Imran, M. A Critical Review of Sustainable Energy Policies for the Promotion of Renewable Energy Sources. Sustainability 2020, 12, 5078. [CrossRef]

20. Solman, H.; Smits, M.; van Vliet, B.; Bush, S. Co-production in the wind energy sector: A systematic literature review of public engagement beyond invited stakeholder participation. Energy Res. Soc. Sci. 2021, 72, 101876. [CrossRef]

21. Renewable Energy Statistics; Technical Report; International Renewable Energy Agency (IRENA): Abu Dhabi, United Arab Emirates, 2021; ISBN 978-92-9260-356-4. Available online: https:/ / www.irena.org/statistics / (accessed on 5 July 2021).

22. Njiri, J.G.; Beganovic, N.; Do, M.H.; Söffker, D. Consideration of lifetime and fatigue load in wind turbine control. Renew. Energy 2019, 131, 818-828. [CrossRef]

23. Stetter, C.; Heumann, M.; Westbomke, M.; Stonis, M.; Breitner, M.H. A Real Options Approach to Determine the Optimal Choice Between Lifetime Extension and Repowering of Wind Turbines. In Operations Research Proceedings 2019; Neufeld, J.S., Buscher, U., Lasch, R., Möst, D., Schönberger, J., Eds.; Springer International Publishing: Cham, Switzerland, 2020; pp. 291-297.

24. Haces-Fernandez, F. GoWInD: Wind Energy Spatiotemporal Assessment and Characterization of End-of-Life Activities. Energies 2020, 13, 6015. [CrossRef]

25. Hache, E.; Palle, A. Renewable energy source integration into power networks, research trends and policy implications: A bibliometric and research actors survey analysis. Energy Policy 2019, 124, 23-35. [CrossRef]

26. Serrano González, J.; Burgos Payán, M.; Santos, J.M.R.; González-Longatt, F. A review and recent developments in the optimal wind-turbine micro-siting problem. Renew. Sustain. Energy Rev. 2014, 30, 133-144. [CrossRef]

27. Pereira, S.; Ferreira, P.; Vaz, A. Optimization modeling to support renewables integration in power systems. Renew. Sustain. Energy Rev. 2016, 55, 316-325. [CrossRef]

28. Sakellariou, N. Current and potential decommissioning scenarios for end-of-life composite wind blades. Energy Syst. 2018, 9, 981-1023. [CrossRef]

29. Mishnaevsky, L. Sustainable End-of-Life Management of Wind Turbine Blades: Overview of Current and Coming Solutions. Materials 2021, 14, 1124. [CrossRef]

30. Pakenham, B.; Ermakova, A.; Mehmanparast, A. A Review of Life Extension Strategies for Offshore Wind Farms Using Techno-Economic Assessments. Energies 2021, 14, 1936. [CrossRef]

31. Topham, E.; González, E.; McMillan, D.; João, E. Challenges of decommissioning offshore wind farms: Overview of the European experience. J. Phys. Conf. Ser. 2019, 1222, 012035. [CrossRef]

32. Piel, J.; Stetter, C.; Heumann, M.; Westbomke, M.; Breitner, M. Lifetime Extension, Repowering or Decommissioning? Decision Support for Operators of Ageing Wind Turbines. J. Phys. Conf. Ser. 2019, 1222, 012033. [CrossRef]

33. Sawant, M.; Thakare, S.; Rao, A.P.; Feijóo-Lorenzo, A.E.; Bokde, N.D. A Review on State-of-the-Art Reviews in Wind-Turbineand Wind-Farm-Related Topics. Energies 2021, 14, 2041. [CrossRef] 
34. Gil-García, I.C.; García-Cascales, M.S.; Fernández-Guillamón, A.; Molina-García, A. Categorization and analysis of relevant factors for optimal locations in onshore and offshore wind power plants: A taxonomic review. J. Mar. Sci. Eng. 2019, 7, 391. [CrossRef]

35. McKenna, R.; vd Leye, P.O.; Fichtner, W. Key challenges and prospects for large wind turbines. Renew. Sustain. Energy Rev. 2016, 53, 1212-1221. [CrossRef]

36. Klunne, W.E.; Beurskens, H.J.M.; Westra, C. Wind Repowering in the Netherlands. Energy Research Centre of the Netherlands ECN. 2001. Available online: https:/ / publicaties.ecn.nl/ (accessed on 5 July 2021).

37. Möller, B. Changing wind-power landscapes: Regional assessment of visual impact on land use and population in Northern Jutland, Denmark. Appl. Energy 2006, 83, 477-494. [CrossRef]

38. Meyerhoff, J.; Ohl, C.; Hartje, V. Landscape externalities from onshore wind power. Energy Policy 2010, 38, 82-92. [CrossRef]

39. Ohl, C.; Eichhorn, M. The mismatch between regional spatial planning for wind power development in Germany and national eligibility criteria for feed-in tariffs-A case study in West Saxony. Land Use Policy 2010, 27, 243-254. [CrossRef]

40. Sperling, K.; Hvelplund, F.; Mathiesen, B.V. Evaluation of wind power planning in Denmark-Towards an integrated perspective. Energy 2010, 35, 5443-5454. [CrossRef]

41. Castro, L.; Filgueira, A.; Seijo, M.; Muñoz, E.; Piegiari, L. Is it economically possible repowering Wind Farms. A general analysis in Spain. RE PQJ 2011, 11, 11. [CrossRef]

42. del Río, P.; Calvo Silvosa, A.; Iglesias Gómez, G. Policies and design elements for the repowering of wind farms: A qualitative analysis of different options. Energy Policy 2011, 39, 1897-1908. [CrossRef]

43. Himpler, S.; Madlener, R. Repowering of Wind Turbines: Economics and Optimal Timing. FCN Working Paper No. $19 / 2011$. 2012. Available online: https:/ / ssrn.com/abstract=2236265 (accessed on 5 July 2021).

44. Madlener, R.; Schumacher, M. Economic Evaluation of the Repowering of Onshore Wind Power Plants in Germany. Z Energiewirtsch 2011, 35, 297-320. [CrossRef]

45. Zimmermann, T.; Goessling-Reisemann, S. Optimal repowering of wind energy converters: Energy demand and $\mathrm{CO}_{2}$ intensity as indicators. In Proceedings of the Life Cycle Management Conference, Berlin, Germany, 28-31 May 2011.

46. Jansen, S. Repowering Strategies for Wind Farms in Northern Germany-A Feasibility Study. Ph.D. Thesis, Vienna School of International Studies, Wien, Austria, 2013.

47. Kalioras, K. Repowering of Small Scale Wind Power Park in the Region of Kastri-Evia Island, Greece. Ph.D. Thesis, KTH Industrial Engineeing and Management, Stockholm, Sweden, 2013.

48. Lantz, E.; Leventhal, M.; Baring-Gould, I. National Renewable Energy Laboratory (NREL). Wind Power Project Repowering: Financial Feasibility, Decision Drivers, and Supply Chain Effects. 2011. Available online: http://www.ntis.gov/help/ ordermethods.aspx (accessed on 5 July 2021).

49. Silvosa, A.C.; Gómez, G.I.; Río, P.D. Analyzing the Techno-Economic Determinants for the Repowering of Wind Farms. Eng. Econ. J. Devoted Probl. Cap. Invest. 2013, 58, 282-303. [CrossRef]

50. Frantál, B. Have Local Government and Public Expectations of Wind Energy Project Benefits Been Met? Implications for Repowering Schemes. J. Environ. Policy Plan. 2015, 17, 217-236. [CrossRef]

51. Colmenar-Santos, A.; Campíñez-Romero, S.; Pérez-Molina, C.; Mur-Pérez, F. Repowering: An actual possibility for wind energy in Spain in a new scenario without feed-in-tariffs. Renew. Sustain. Energy Rev. 2015, 41, 319-337. [CrossRef]

52. Prabu, T.; Kottayil, S.K. Repowering a Windfarm-A Techno-Economic Approach. Wind Eng. 2015, 39, 385-398. [CrossRef]

53. Dahl, E.L.; May, R.; Nygard, T.; Astrom, J.; Diserud, O.H.; Reitan, R. Repowering Smola wind-power plant. An assessment of avian conflicts. Nor. Inst. Nat. Res. 2015, 1135, 41.

54. Weiss, T. Wind Power Project Development: Financial Viability of Repowering with RETScreen as a Decision Aid Tool. Ph.D Thesis, Department of Earth Sciences, Uppsala University, Uppsala, Sweden, 2015. Available online: http://uu.diva-portal.org/ smash/get/diva2:840649/FULLTEXT01.pdf (accessed on 5 July 2021).

55. Lantz, E.; Mai, T.; Wiser, R.H.; Krishnan, V. Long-term implications of sustained wind power growth in the United States: Direct electric system impacts and costs. Appl. Energy 2016, 179, 832-846. [CrossRef]

56. Oliver Genovés, J. Análisis de Viabilidad de una Actuación de Repowering de un Parque Eólico de $1^{\text {a }}$ Generación de 30 MW con Aerogeneradores de Tecnologia Actual en Tarifa. (In Spanish). Ph.D. Thesis, Universitat Politècnica de València, Valencia, Spain, 2016.

57. Paul, A.; Prabu, T. Technical and economic feasibility study on repowering of wind farms. Indian J. Sci. Technol. 2016, 9, 1-9. [CrossRef]

58. Romano, T.; Mennel, T.; Scatasta, S. Comparing feed-in tariffs and renewable obligation certificates: The case of repowering wind farms. Econ. Polit. Ind. 2017, 44, 291-314. [CrossRef]

59. Serri, L.; Lembo, E.; Airoldi, D.; Gelli, C.; Beccarello, M. Wind energy plants repowering potential in Italy: Technical-economic assessment. Renew. Energy 2018, 115, 382-390. [CrossRef]

60. Jung, C.; Schindler, D.; Grau, L. Achieving Germany's wind energy expansion target with an improved wind turbine siting approach. Energy Convers. Manag. 2018, 173, 383-398. [CrossRef]

61. Ramírez, F.J.; Honrubia-Escribano, A.; Gómez-Lázaro, E.; Pham, D.T. The role of wind energy production in addressing the European renewable energy targets: The case of Spain. J. Clean. Prod. 2018, 196, 1198-1212. [CrossRef] 
62. Villena-Ruiz, R.; Ramirez, F.J.; Honrubia-Escribano, A.; Gómez-Lázaro, E. A techno-economic analysis of a real wind farm repowering experience: The Malpica case. Energy Convers. Manag. 2018, 172, 182-199. [CrossRef]

63. Ziegler, L.; Gonzalez, E.; Rubert, T.; Smolka, U.; Melero, J.J. Lifetime extension of onshore wind turbines: A review covering Germany, Spain, Denmark, and the UK. Renew. Sustain. Energy Rev. 2018, 82, 1261-1271. [CrossRef]

64. Madlener, R.; Glensk, B.; Gläsel, L. Optimal Timing of Onshore Wind Repowering in Germany under Policy Regime Changes: A Real Options Analysis. Energies 2019, 12, 4703. [CrossRef]

65. Manchado, C.; Gomez-Jauregui, V.; Lizcano, P.E.; Iglesias, A.; Galvez, A.; Otero, C. Wind farm repowering guided by visual impact criteria. Renew. Energy 2019, 135, 197-207. [CrossRef]

66. Michaud, S. Techno-Economic Analysis of Wind Farm Repowering Strategies in France. Ph.D. Thesis, KTH Royal Institute of Technology, Stockholm, Sweden, 2010.

67. Vicente-Ramírez, J.; García-Vásquez, E.; Iracheta-Cortez, R.; Dorrego-Portela, J. Economic feasibility study for the repowering of La Venta I and La Venta II wind farms in Mexico. In Proceedings of the IEEE 39th Central America and Panama Convention (CONCAPAN XXXIX), Guatemala City, Guatemala, 20-22 November 2019. [CrossRef]

68. Kitzing, L.; Jensen, M.K.; Telsnig, T.; Lantz, E. Multifaceted drivers for onshore wind energy repowering and their implications for energy transition. Nat. Energy 2020, 5, 1012-1021. [CrossRef]

69. Pryor, S.; Barthelmie, R.; Shepherd, T. $20 \%$ of US electricity from wind will have limited impacts on system efficiency and regional climate. Sci. Rep. 2020, 10, 1-14. [CrossRef]

70. de Bona, J.C.; Ferreira, J.C.E.; Ordoñez Duran, J.F. Analysis of scenarios for repowering wind farms in Brazil. Renew. Sustain. Energy Rev. 2021, 135, 110197. [CrossRef]

71. Grau, L.; Jung, C.; Schindler, D. Sounding out the repowering potential of wind energy-A scenario-based assessment from Germany. J. Clean. Prod. 2021, 293, 126094. [CrossRef]

72. Al Hamed, H. Onshore Wind Farm Repowering Alternative Scenarios and Cost Assessment. Ph.D. Thesis, Department of Earth Sciences, Uppsala University, Uppsala, Sweden, 2021. Available online: http://www.diva-portal.org/smash/get/diva2: 1530274/FULLTEXT01.pdf (accessed on 5 July 2021).

73. Gil-García, I. Integración del Recurso Eólico Marino en los Sectores del Transporte y Climatización: Estudio de Transición Energética en la Costa Este de EEUU (In Spanish). Ph.D. Thesis, Universidad Politécnica de Cartagena, Cartagena, Spain, 2020.

74. Hötker, H. The Impact of Repowering of Wind Farmson Birds and Bats; Michael-Otto-Institute within NABU: Bergenhusen, Germany, 2006.

75. Smallwood, K.S.; Neher, L.; Bell, D.A. Map-Based Repowering and Reorganization of a Wind Resource Area toMinimize Burrowing Owl and Other Bird Fatalities. Energies 2009, 2, 915-943. [CrossRef]

76. Goyal, M. Repowering-Next big thing in India. Renew. Sustain. Energy Rev. 2010, 14, 1400-1409. [CrossRef]

77. Smallwood, K.S.; Bell, D.A.; Snyder, S.A.; DiDonato, J.E. Novel scavenger removal trials increase wind turbine-Caused avian fatality estimates. J. Wildl. Manag. 2010, 74, 1089-1096. [CrossRef]

78. Sen, N.; Ahmed, S.; Lanjewar, A. RE-powering potential of Indian wind farms: A review. Int. J. Eng. Res. Appl. 2012, 2, 1269-1276.

79. Zimmermann, T. Assessing repowering and update scenarios for wind energy converters. In Proceedings of the 25th International Conference on Efficiency, Cost, Optimization and Simulation of Energy Conversion Systems and Processes, Perugia, Italy, 26-29 June 2012.

80. Nivedh, B.; Kumudini-Devi, R.; Sreevalsanc, E. Repowering of Wind Farms-A Case Study. Wind Eng. 2013, 37, 137-150. [CrossRef]

81. Rodríguez, R.; Rodríguez-Monroy, C.; Rodríguez, R.; Calvo, F. Analysis of Renewable Energy Policies Related to Repowering the Wind Energy Sector: The Spanish Case. In Proceedings of the 11th Latin American and Caribbean Conference for Engineering and Technology, Cancun, Mexico, 14-16 August 2012.

82. Everaert, J. Collision risk and micro-avoidance rates of birds with wind turbines in Flanders. Bird Study 2014, 61, 220-230. [CrossRef]

83. Marques, A.T.; Batalha, H.; Rodrigues, S.; Costa, H.; Pereira, M.J.R.; Fonseca, C.; Mascarenhas, M.; Bernardino, J. Understanding bird collisions at wind farms: An updated review on the causes and possible mitigation strategies. Biol. Conserv. 2014, 179, 40-52. [CrossRef]

84. Arnett, E.B.; May, R.F. Mitigating wind energy impacts on wildlife: Approaches for multiple taxa. Hum.-Wildl. Interact. $2016,10,5$.

85. Castro-Santos, L.; Vizoso, A.F.; Camacho, E.M.; Piegiari, L. Costs and feasibility of repowering wind farms. Energy Sources B Econ. Plan. Policy 2016, 11, 974-981. [CrossRef]

86. Ferri, V.; Battisti, C.; Soccini, C. Bats in a Mediterranean mountainous landscape: Does wind farm repowering induce changes at assemblage and species level? Environ. Manag. 2016, 57, 1240-1246. [CrossRef]

87. Mendez, J.; Lopez, G. Limits of Repowering Renewable Sources in Electric Islands. In Proceedings of the International Conference on Modern Electrical Power Engineering-ICMEPE'16, Las Palmas de Gran Canaria, Spain, 6-8 July 2016.

88. Santos-Alamillos, F.; Thomaidis, N.; Usaola-García, J.; Ruiz-Arias, J.; Pozo-Vázquez, D. Exploring the mean-variance portfolio optimization approach for planning wind repowering actions in Spain. Renew. Energy 2017, 106, 335-342. [CrossRef]

89. Shawn Smallwood, K. The Challenges of Addressing Wildife Impacts When Repowering Wind Energy Projects; Springer International Publishing: Berlin, Germany, 2017; pp. 175-187. [CrossRef] 
90. Karoui, R.; Khadraoui, H.; Bacha, F. Repowering of the Wind Farm of Sidi-Daoud Tunisia. In Proceedings of the International Conference on Advanced Systems and Electric Technologies, Hammamet, Tunisia, 14-17 January 2017.

91. Karoui, R.; Bacha, F.; Hasni, A.; Khadraoui, H. Analysis of the Repowering Wind Farm of Sidi-Daoud in Tunisia. IEEE Trans. Ind. Appl. 2018, 55, 3011-3023. [CrossRef]

92. Martínez, E.; Latorre-Biel, J.; Jiménez, E.; Sanz, F.; Blanco, J. Life cycle assessment of a wind farm repowering process. Renew. Sustain. Energy Rev. 2018, 93, 260-271. [CrossRef]

93. Watson, R.T.; Kolar, P.S.; Ferrer, M.; Nygård, T.; Johnston, N.; Hunt, W.G.; Smit-Robinson, H.A.; Farmer, C.J.; Huso, M.; Katzner, T.E. Raptor interactions with wind energy: Case studies from around the world. J. Raptor Res. 2018, 52, 1-18. [CrossRef]

94. Kadhirvel, B.; Ramaswamy, S.; Kirubaharan, V.; Bastin, J.; ShobanaDevi, A.; Kanagavel, P.; Balaraman, K. Optimization of the Wind Farm Layout by Repowering the old Wind Farm and integrating Solar Power Plants: A Case Study. Int. J. Renew. Energy Res. (IJRER) 2020, 10, 1287-1301.

95. Das, A.; Jani, H.K.; Kachhwaha, S.S.; Nagababu, G. Assessment of Factors Affecting Onshore Wind Power Deployment in India. Sci. J. Riga Tech. Univ. Environ. Clim. Technol. 2020, 24, 185-208. [CrossRef]

96. Fuchs, C.; Kasten, J.; Vent, M. Current State and Future Prospective of Repowering Wind Turbines: An Economic Analysis. Energies 2020, 13, 3048. [CrossRef]

97. Guan, J. Westerly breezes and easterly gales: A comparison of legal, policy and planning regimes governing onshore wind in Germany and China. Energy Res. Soc. Sci. 2020, 67, 101506. [CrossRef]

98. Syed, A.H.; Javed, A.; Feroz, R.M.A.; Calhoun, R. Partial repowering analysis of a wind farm by turbine hub height variation to mitigate neighboring wind farm wake interference using mesoscale simulations. Appl. Energy 2020, 268, 115050. [CrossRef]

99. Hu, Y.; Yang, J.; Baniotopoulos, C. Repowering Steel Tubular Wind Turbine Towers Enhancing them by Internal Stiffening Rings. Energies 2020, 13, 1538. [CrossRef]

100. Huso, M.; Conkling, T.; Dalthorp, D.; Davis, M.; Smith, H.; Fesnock, A.; Katzner, T. Relative energy production determines effect of repowering on wildlife mortality at wind energy facilities. J. Appl. Ecol. 2021, 56, 1284-1290. [CrossRef]

101. Lacal-Arántegui, R.; Uihlein, A.; Yusta, J.M. Technology effects in repowering wind turbines. Wind Energy 2020, $23,660-675$. [CrossRef]

102. Schaub, T.; Klaassen, R.H.; Bouten, W.; Schlaich, A.E.; Koks, B.J. Collision risk of Montagu's Harriers Circus pygargus with wind turbines derived from high-resolution GPS tracking. Ibis 2020, 162, 520-534. [CrossRef]

103. Szumilas-Kowalczyk, H.; Pevzner, N.; Giedych, R. Long-term visual impacts of aging infrastructure: Challenges of decommissioning wind power infrastructure and a survey of alternative strategies. Renew. Energy 2020, 150, 550-560. [CrossRef]

104. Gulatowski-Henk, M. Public Attitude Towards Wind Power in a Developed and a Developing Wind Market-Case Study of Spain and Poland; Uppsala Universitet: Uppsala, Sweden, 2017. Available online: http://uu.diva-portal.org/smash/get/diva2: 1116807/FULLTEXT01.pdf (accessed on 5 July 2021).

105. Bezbradica, M.; Kerkvliet, H.; Borbolla, I.M.; Lehtimäki, P. Introducing multi-criteria decision analysis for wind farm repowering: A case study on Gotland. In Proceedings of the International Conference Multidisciplinary Engineering Design Optimization (IEEE-MEDO), Belgrade, Serbia, 14-16 September 2016; pp. 1-8.

106. Hou, P.; Enevoldsen, P.; Hu, W.; Chen, C.; Chen, Z. Offshore wind farm repowering optimization. Appl. Energy 2017, 208, 834-844. [CrossRef]

107. He, W.; Grant, R.J.; Baden, V.; Suntharalingam, J. Innovative alternatives for repowering offshore wind farms. J. Phys. Conf. Ser. 2020, 1618, 042037. [CrossRef]

108. Bergvall, D. Cost Comparison of Repowering Alternatives for Offshore Wind Farms. Ph.D. Thesis, Disciplinary Domain of Science and Technology, Earth Sciences, Department of Earth Sciences, Uppsala University, Uppsala, Sweden, 2019. Available online: https: / / www.diva-portal.org/ (accessed on 5 July 2021).

109. Sun, H.; Gao, X.; Yang, H. Investigation into offshore wind farm repowering optimization in Hong Kong. Int. J.-Low-Carbon Technol. 2019, 14, 302-311. [CrossRef]

110. Hassan, M.B. Futureproof Offshore Wind Turbine Foundations-Reducing LCOE and Environmental Impacts through Repowering Focused Selection. Ph.D. Thesis, Reykjavík University, Reykjavík, Iceland, August 2020. Available online: https://skemman.is / handle/1946/37113 (accessed on 5 July 2021).

111. Zuo, T.; Zhang, Y.; Meng, K.; Tong, Z.; Dong, Z.Y.; Fu, Y. Collector System Topology Design for Offshore Wind Farm's Repowering and Expansion. IEEE Trans. Sustain. Energy 2021, 12, 847-859. [CrossRef]

112. Jadali, A.M.; Ioannou, A.; Salonitis, K.; Kolios, A. Decommissioning vs. repowering of offshore wind farms-A techno-economic assessment. Int. J. Adv. Manuf. Technol. 2021, 112, 2519-2532. [CrossRef]

113. Renewable Power Generation Costs in 2020; Technical Report; International Renewable Energy Agency (IRENA): Abu Dhabi, United Arab Emirates, June 2021; ISBN 978-92-9260-348-9. Available online: http://www.irena.org/publications/ (accessed on 5 July 2021).

114. 1991-2001 The First Offshore Wind Farms. Making Green Energy Affordable. Technical Report, Ørsted A/S, Denmark. Available online: https:/ / orsted.com/en/about-us/whitepapers / making-green-energy-affordable/1991-to-2001-the-first-offshore-windfarms (accessed on 5 July 2021).

115. Global Wind Report 2020. Technical Report, Global Wind Energy Council (GWEC), 2021. Available online: https://www.gwec.net (Accessed on 5 July 2021). 
116. Goch, G.; Knapp, W.; Härtig, F. Precision engineering for wind energy systems. CIRP Ann. 2012, 61, 611-634. [CrossRef]

117. Renewable Energy. Technical Report, European Commission (EU), 2021. Available online: https://ec.europa.eu/energy/topics/ renewable-energy_en (accessed on 5 July 2021).

118. Tambach, M.; Hasselaar, E.; Itard, L. Assessment of current Dutch energy transition policy instruments for the existing housing stock. Energy Policy 2010, 38, 981-996. [CrossRef]

119. Meyer, N.I. Learning from wind energy policy in the EU: Lessons from Denmark, Sweden and Spain. Eur. Environ. 2007, 17, 347-362. [CrossRef] 